\title{
Biodegradation by bacteria in clouds: an underestimated sink for some organics in the atmospheric multiphase system
}

\author{
Amina Khaled, Minghui Zhang, Pierre Amato, Anne-Marie Delort, and Barbara Ervens \\ Université Clermont Auvergne, CNRS, SIGMA Clermont, Institut de Chimie de Clermont-Ferrand, \\ 63000 Clermont-Ferrand, France
}

Correspondence: Amina Khaled (amina.khaled@uca.fr)

Received: 27 July 2020 - Discussion started: 13 August 2020

Revised: 10 January 2021 - Accepted: 11 January 2021 - Published: 2 March 2021

\begin{abstract}
Water-soluble organic compounds represent a significant fraction of total atmospheric carbon. The main oxidants towards them in the gas and aqueous phases are $\mathrm{OH}$ and $\mathrm{NO}_{3}$ radicals. In addition to chemical solutes, a great variety of microorganisms (e.g., bacteria, viruses, fungi) have been identified in cloud water. Previous lab studies suggested that for some organics, biodegradation by bacteria in water is comparable to their loss by chemical processes. We perform model sensitivity studies over large ranges of biological and chemical process parameters using a box model with a detailed atmospheric multiphase chemical mechanism and biodegradation processes to explore the importance of biodegradation of organics in the aqueous phase. Accounting for the fact that only a small number fraction of cloud droplets $(\sim 0.0001-0.001)$ contains active bacterial cells, we consider only a few bacteria-containing droplets in the model cloud. We demonstrate that biodegradation might be most efficient for water-soluble organic gases with intermediate solubility $\left(\sim 10^{4} \leq K_{\mathrm{H}(\text { eff })}\left[\mathrm{M} \mathrm{atm}^{-1}\right] \leq 10^{6}\right.$, e.g., formic and acetic acids). This can be explained by the transport limitation due to evaporation of organics from bacteriafree droplets to the gas phase, followed by the dissolution into bacteria-containing droplets. For cloud condensation nuclei (CCN)-derived compounds, such as dicarboxylic acids, the upper limit of organic loss by biodegradation can be approximated by the amount of organics dissolved in the bacteria-containing droplets $(<0.1 \%)$. We compare results from our detailed drop-resolved model to simplified model approaches, in which (i) either all cloud droplets are assumed to contain the same cell concentration (0.0001-0.001 cell per droplet), or (ii) only droplets with intact bacterial cells are considered in the cloud (liquid water content
\end{abstract}

$\left.\sim 10^{-11} \mathrm{vol} / \mathrm{vol}\right)$. Conclusions based on these approaches generally overestimate the role of biodegradation, particularly for highly water-soluble organic gases. Our model sensitivity studies suggest that current atmospheric multiphase chemistry models are incomplete for organics with intermediate solubility and high bacterial activity.

\section{Introduction}

Clouds provide a medium for multiphase chemical reactions, in which chemical species from the aqueous, solid, and gas phases are transformed and can affect significantly the transport and distribution of chemical species in the atmosphere (Lelieveld and Crutzen, 1991). The chemical composition of cloud water is a complex mixture containing a multitude of organic and inorganic species with a range of chemical and physical properties (e.g., reactivity, solubility, volatility). The organic fraction includes water-soluble organic gases and water-soluble cloud condensation nuclei (CCN)derived components, such as aldehydes, mono- and dicarboxylic acids, and organonitrogen and organosulfur compounds. Water-soluble organic gases are dissolved from the gas phase to the aqueous phase; $\mathrm{CCN}$-derived compounds enter the aqueous phase via nucleation scavenging of condensation nuclei (CCN) (Ervens, 2015; Löflund et al., 2002). Water-soluble organic carbon (WSOC) constitutes a significant portion of the total atmospheric organic carbon mass, ranging from $\sim 14 \%$ to $\sim 64 \%$ depending on the sampling location (Decesari et al., 2000; Gao et al., 2016; Varga et al., 2001). 
In addition to chemical solutes, cloud water contains microorganisms such as bacteria, yeast, and fungi (Delort et al., 2010; Hu et al., 2018). Typical concentrations of bacterial cells are on the order of $10^{6}$ to $10^{8}$ cells $\mathrm{L}^{-1}$; fungi and yeast cell concentrations are usually lower $\left(\sim 10^{5}\right.$ to $\sim 10^{7}$ cells L $^{-1}$ ) (Amato et al., 2007b; Sattler et al., 2001). The atmosphere is a stressful environment for microorganisms (low temperature, UV exposure, acidic $\mathrm{pH}$, quick hydration-drying cycles, and the presence of oxidants such as $\mathrm{OH}$ and $\mathrm{H}_{2} \mathrm{O}_{2}$ ) (Sattler et al., 2001), which might limit the survival time of cells in the atmosphere.

Several studies have shown that bacteria can grow and be metabolically active in cloud droplets. Marker compounds such as adenosine $5^{\prime}$-triphosphate (ATP) (Amato et al., 2007c), rRNA (Krumins et al., 2014a), or mRNA (Amato et al., 2019) have been used to demonstrate metabolic activity in the atmosphere. The ADP / ATP ratio (where ADP is adenosine diphosphate), monitored during lab experiments with real cloud water, showed that even after exposure to oxidants over several hours, biodegradation rates were not significantly affected (Vaïtilingom et al., 2013). Metabolic activity and cell generation of bacteria is likely restricted to the time cells spend in clouds due to the abundance of liquid water (Ervens and Amato, 2020; Haddrell and Thomas, 2017); bacteria have been found to be dormant at lower relative humidity than in clouds (Kaprelyants and Kell, 1993).

The metabolic activity of bacterial strains identified in cloud water (e.g., Pseudomonas, Sphingomonas) has been investigated in lab studies, and it was shown that they can biodegrade organics (e.g., malonate, succinate, adipate, pimelate, formaldehyde, methanol, acetate, formate, phenol, and catechol) (Amato et al., 2007a; Ariya et al., 2002; Delort et al., 2010; Fankhauser et al., 2019; Husárová et al., 2011; Jaber et al., 2020; Vaïtilingom et al., 2010, 2011, 2013). Based on comparisons of experimentally derived biodegradation rates to chemical rates of oxidation reactions by radicals (e.g., $\mathrm{OH}, \mathrm{NO}_{3}$ ) in the aqueous phase, it was concluded that they might be similar under some conditions and that, depending on the abundance and metabolic activity of bacteria strains, oxidation and biodegradation processes of organics may compete in clouds. The biodegradation rate likely depends on the availability of the substrate in the aqueous phase. In the case of soluble substrates, it can be expected that uptake of soluble substrates from the gas phase leads to a continuous replenishment of the organics.

There are several estimates of WSOC loss by bacteria on a global scale: Sattler et al. (2001) estimated a sink of $1-10 \mathrm{Tg} \mathrm{yr}^{-1}$, smaller than the estimate by Vaïtilingom et al. (2013) (10-50 $\left.\mathrm{Tg} \mathrm{yr}^{-1}\right)$. However, the latter is likely an overestimate as complete respiration was implied, i.e., total conversion of organics into $\mathrm{CO}_{2}$. More conservatively, Ervens and Amato (2020) suggested a global WSOC loss of $8-$ $11 \mathrm{Tg} \mathrm{yr}^{-1}$, being comparable to that by chemical processes (8-20 $\left.\mathrm{Tg} \mathrm{yr}^{-1}\right)$. Similarly, Fankhauser et al. (2019) postu- lated that the role of biodegradation is likely small, but they did not quantify the loss of different organics by bacteria.

Current atmospheric multiphase chemistry models include chemical mechanisms of different complexity with up to thousands of chemical reactions describing the transformation of inorganic and organic compounds, e.g., (Ervens et al., 2003a; Mouchel-Vallon et al., 2017; Tilgner et al., 2013; Woo and McNeill, 2015). However, they do not include the biodegradation of organics by bacteria despite the available data sets discussed above.

Cloud chemistry models often assume initially identical composition of all cloud droplets. While this might be a reasonable assumption for the chemical droplet composition due to internally mixed $\mathrm{CCN}$ and the phase transfer from the gas phase into all droplets, it is not appropriate for the distribution of bacteria. Due to their small number fraction of the total CCN concentration $(0.001 \%-0.1 \%$, e.g., Zhang et al., 2020), the fraction of cloud droplets that contain bacterial cells is small $(<0.001)$. Thus, to explore biodegradation of organics in the atmospheric multiphase system, a realistic distribution within cloud droplet population needs to be assumed.

The aim of our study is to identify conditions under which biodegradation in clouds is significant in the atmosphere. Using a cloud multiphase box model, we explore the biological and chemical degradation of organic compounds over large parameter ranges of biodegradation activities, chemical rate constants, and Henry's law constants. We compare (1) the biodegradation rates in the aqueous phase to the chemical rates in both phases and (2) the fraction of organics consumed by biodegradation to that by chemical processes. The results of our sensitivity studies elucidate the organics for which biodegradation competes with chemical processes. Our study will give guidance for future experimental and modeling studies to further complete atmospheric models in order to more comprehensively describe organic degradation in the atmosphere.

\section{Methods}

\subsection{Description of the multiphase box model}

We use a multiphase box model with detailed gas- and aqueous-phase chemistry (75 species, 44 gas-phase reactions, 31 aqueous reactions) (Ervens et al., 2008).

The chemical aqueous-phase mechanism with rate constants is listed in Table S1 in the Supplement. The chemical gas-phase mechanism is based on the NCAR Master Mechanism (Aumont et al., 2000; Madronich and Calvert, 1989).

The two phases are coupled by 26 phase transfer processes which are described kinetically based on the resistance model by Schwartz (1986). The parameters describing the phase transfer of the soluble species are presented in Table S2. In addition, the initial mixing ratios of gas- 
(a) Water-soluble organic gases

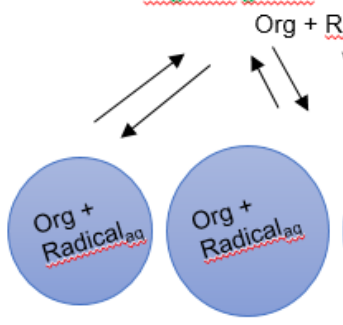

Org + Radical

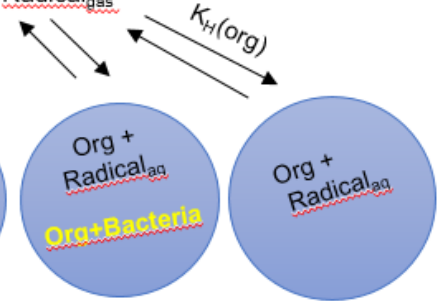

(b) $\mathrm{CCN}$-derived compounds
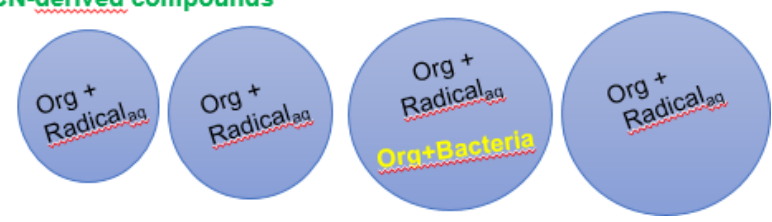

Figure 1. Schematic of the multiphase box model including chemical radical reactions in the gas and aqueous phases. Chemical reactions occur in both phases and in all droplets, whereas biodegradation processes only occur in the aqueous phase in a small fraction of droplets, depending on the assumed bacterial cell concentration in clouds. (a) Water-soluble organic gases that partition between the two phases; (b) $\mathrm{CCN}$-derived compounds that only get processed in the aqueous phase.

phase species are included in Table S3. The equations for the mass transfer coefficient $k_{\mathrm{mt}}$ and the differential equations for the aqueous- and gas-phase concentrations can be found in the Supplement (Eq. S1-S3; Section "Description of phase transfer") (Seinfeld and Pandis, 1998). In addition to the base chemical mechanism, we define one organic species "Org" that undergoes chemical radical reactions in the gas and aqueous phases and biodegradation by bacteria only in the aqueous phase in a small subset of the droplets as shown in Fig. 1. We consider a polydisperse droplet population of 263 droplets $\mathrm{cm}^{-3}$ in 11 size classes with drop diameters of $5 \mu \mathrm{m} \leq D_{\text {droplet }} \leq 30 \mu \mathrm{m}$ and a total liquid water content of $\mathrm{LWC}=6.8 \times 10^{-7} \mathrm{vol} / \mathrm{vol}$. Only one droplet size class includes bacterial cells $\left(D_{\text {droplet }}=20 \mu \mathrm{m} ; N_{\text {droplet }}=\right.$ cell concentration $=0.01 \mathrm{~cm}\left(\mathrm{gas}^{-3}\right)$. Thus, the cell concentration in the cloud water $\left(C_{\text {cell, aq }}=1.5 \times 10^{7}\right.$ cell $\left.\mathrm{L}^{-1}\right)$ is similar to that found in ambient clouds and as used in lab experiments (Vaiitilingom et al., 2013). The model simulations are performed for $600 \mathrm{~s}$, which corresponds approximately to the droplet lifetime during one cloud cycle (Ervens et al., 2004).

We categorize four various compound groups based on their solubility in water and their Henry's law constant, and we distinguish the following:

1. Low-solubility species with $K_{\mathrm{H}}<10^{3} \mathrm{Matm}^{-1}$. Their dissolved fraction is $<1 \%$ for the liquid water content (LWC) of $0.68 \mathrm{~g} \mathrm{~m}^{-3}$ in our model.

2. Intermediate-solubility species with $10^{3} \mathrm{Matm}^{-1}<$ $K_{\mathrm{H}}<10^{6} \mathrm{M} \mathrm{atm}^{-1}$ with dissolved fractions of $\sim 1 \%-$ $95 \%\left(\mathrm{LWC}=0.68 \mathrm{~g} \mathrm{~m}^{-3}\right)$.
3. High-solubility species with $K_{\mathrm{H}}>10^{6} \mathrm{Matm}^{-1}$ for which the dissolved fraction exceeds $95 \%(\mathrm{LWC}=$ $0.68 \mathrm{~g} \mathrm{~m}^{-3}$ ).

4. Water-soluble CCN components which are dissolved in the aqueous phase upon dissolution of the condensation nucleus on which the cloud droplet grew. While these compounds have usually low volatility or are semivolatile, they also need to be water soluble to be available for aqueous-phase processes.

\subsection{Kinetic data in the gas and aqueous phases}

\subsubsection{Chemical rates and Henry's law constants}

Table 1 includes chemical rate constants for radical $(\mathrm{OH}$, $\mathrm{NO}_{3}$ ) reactions in the aqueous and gas phases for organic compounds, for which lab data on their biodegradation rates are available (Sect. 2.2.2). These data cover ranges of $10^{3} \leq$ $k_{\text {chemaq }}\left[\mathrm{M}^{-1} \mathrm{~s}^{-1}\right] \leq 10^{10}$ and $10^{-17} \leq k_{\text {chemgas }}\left[\mathrm{cm}^{3} \mathrm{~s}^{-1}\right]$ $\leq 10^{-10}$, respectively, over which the model sensitivity studies in the following are performed.

In order to generalize our results for different radical concentrations, we present them in terms of chemical rates $R_{\text {chem }}$ $\left[\mathrm{s}^{-1}\right.$ ], i.e., as the products of the rate constants $k_{\text {chemaq }}$ and $k_{\text {chemgas }}$ and radical concentrations:

$$
\begin{aligned}
& R_{\text {chemaq }}\left[\mathrm{s}^{-1}\right]=\frac{-\mathrm{d}(\mathrm{Org})_{\text {radical }}}{\mathrm{d} t} \\
& \quad=k_{\text {chemaq }}\left[\mathrm{L} \mathrm{mol}^{-1} \mathrm{~s}^{-1}\right] \times[\text { radical }]_{\mathrm{aq}}\left[\mathrm{mol} \mathrm{L}^{-1}\right], \\
& R_{\text {chemgas }}\left[\mathrm{s}^{-1}\right]=\frac{-\mathrm{d}(\mathrm{Org})_{\text {radical }}}{\mathrm{d} t} \\
& \quad=k_{\text {chemgas }}\left[\mathrm{cm}^{3} \mathrm{~s}^{-1}\right] \times[\text { radical }]_{\mathrm{gas}}\left[\mathrm{cm}^{-3}\right] .
\end{aligned}
$$

Typical radical concentrations are on the order of $10^{-15} \mathrm{molL}^{-1}$ for $\mathrm{OH}$ and $\mathrm{NO}_{3}$ radicals in the aqueous phase of clouds (Arakaki et al., 2013; Herrmann, 2003) and $10^{6}$ and $10^{7}-10^{8} \mathrm{~cm}^{-3}$ in the gas phase, respectively (Cantrell et al., 1997; Khan et al., 2008). The Henry's law constants for the same organic compounds are also listed in Table 1. They cover a range of $10^{2} \leq K_{\mathrm{H}}\left[\mathrm{M} \mathrm{atm}^{-1}\right] \leq 10^{9}$. For carboxylic acids, we also report effective Henry's law constants at $\mathrm{pH}=3$ and $\mathrm{pH}=6$ as being typical for cloud water.

\subsubsection{Biodegradation rates}

In the literature, experimental rates for metabolic processes are usually reported in units of $\left[\mathrm{mol} \mathrm{cell} \mathrm{l}^{-1} \mathrm{~s}^{-1}\right]$ (Table 2). We converted these rates into first-order loss rates $k_{\text {bact }}^{1 s t}\left[\mathrm{~s}^{-1}\right]$ by dividing them by the ratio of the concentration of the organic compound $\left[\mathrm{mol} \mathrm{L}^{-1}\right.$ ] to $C_{\text {cell, aq }}$ [cell $\mathrm{L}^{-1}$ ] used in the respective experiments. To obtain a value with units corresponding to chemical rate constants, this rate is divided by the constant model cell concentration $\left(C_{\text {cell, aq }}=1.5 \times 10^{7}\right.$ cell $\left.^{-1}\right)$ resulting in a range of $10^{-18} \leq k_{\text {bact }}\left[\mathrm{L} \mathrm{cell}^{-1} \mathrm{~s}^{-1}\right] \leq 10^{-11}$. 
Table 1. Literature data on chemical rate constants in the aqueous $\left(k_{\mathrm{OH}, \text { aq }} ; k_{\mathrm{NO}_{3}, \text { aq }}\right)$ and gas phases $\left(k_{\mathrm{OH}_{\text {,gas }}} ; k_{\mathrm{NO}_{3} \text {,gas }}\right)$ and physical Henry's law constants $\left(K_{\mathrm{H}}\right)$ and effective Henry's law constants $\left(K_{\mathrm{H}(\mathrm{eff})}\right)$ for acids at $\mathrm{pH}=3$ and $\mathrm{pH}=6$, respectively.

\begin{tabular}{|c|c|c|c|c|c|c|c|}
\hline Organic compounds & $\begin{array}{r}k_{\mathrm{OH}, \mathrm{aq}}\left(25^{\circ} \mathrm{C}\right) \\
{\left[\mathrm{M}^{-1} \mathrm{~s}^{-1}\right]}\end{array}$ & $\begin{array}{r}k_{\mathrm{OH}, \text { gas }}\left(25^{\circ} \mathrm{C}\right) \\
{\left[\mathrm{cm}^{3} \mathrm{~s}^{-1}\right]}\end{array}$ & $\begin{array}{r}k_{\mathrm{NO}_{3}, \mathrm{aq}} \\
{\left[\mathrm{M}^{-1} \mathrm{~s}^{-1}\right]}\end{array}$ & $\begin{array}{r}k_{\mathrm{NO}_{3}, \text { gas }} \\
{\left[\mathrm{cm}^{3} \mathrm{~s}^{-1}\right]}\end{array}$ & $\begin{array}{r}K_{\mathrm{H}} \\
{\left[\mathrm{M} \mathrm{atm}^{-1}\right]}\end{array}$ & $\mathrm{pK}_{\mathrm{a}}$ & $\begin{array}{r}K_{\mathrm{H}(\text { eff })} \\
{\left[\mathrm{M} \mathrm{atm}^{-1}\right]} \\
\text { at } \mathrm{pH}=3, \\
\mathrm{pH}=6\end{array}$ \\
\hline \multicolumn{8}{|c|}{ CCN-derived compounds } \\
\hline Malonic acid & $1.6 \times 10^{7}$ & & $5.1 \times 10^{4}(1)$ & & & & \\
\hline Malonate monoanion & $3.6 \times 10^{8}(1)$ & & $\begin{array}{l}5.6 \times 10^{6}(1) \\
2.3 \times 10^{7}(1)\end{array}$ & & $1.23 \times 10^{10}(12)$ & $\begin{array}{l}2.8 \\
5.6\end{array}$ & $\begin{array}{l}3.18 \times 10^{10} \\
6.84 \times 10^{13}\end{array}$ \\
\hline Malonate dianion & $8.0 \times 10^{7}(1)$ & & & & & & \\
\hline Succinic acid & $3.8 \times 10^{8}(2)$ & & $5 \times 10^{3}(1)$ & & $3.5 \times 10^{9}(12)$ & $\begin{array}{l}4.23 \\
5.64\end{array}$ & $\begin{array}{l}3.70 \times 10^{10} \\
6.81 \times 10^{11}\end{array}$ \\
\hline Succinate monoanion & $5 \times 10^{8}(1)$ & & $\begin{array}{l}1.1 \times 10^{7}(1) \\
1.8 \times 10^{7}(1)\end{array}$ & & & & \\
\hline Succinate dianion & $5 \times 10^{8}(5)$ & & & & & & \\
\hline \multicolumn{8}{|c|}{ Water-soluble organic gases } \\
\hline Acetic acid & $1.6 \times 10^{7}(3)$ & $6.6 \times 10^{-13}(6)$ & $1.3 \times 10^{4}(8)$ & - & $7 \times 10^{3}(13)$ & 4.75 & $\begin{array}{l}7.1 \times 10^{3} \\
1.3 \times 10^{5}\end{array}$ \\
\hline Acetate & $8.5 \times 10^{7}(1)$ & & $2.3 \times 10^{6}(8)$ & & & & \\
\hline Formic acid & $1.3 \times 10^{8}(3)$ & $1.3 \times 10^{-12}(7)$ & $3.3 \times 10^{4}(1)$ & - & $11 \times 10^{3}(13)$ & 3.76 & $\begin{array}{l}1.2 \times 10^{4} \\
1.9 \times 10^{6}\end{array}$ \\
\hline Formate & $3.2 \times 10^{9}(1)$ & & $4.2 \times 10^{7}(1)$ & & & - & - \\
\hline Formaldehyde & $6.1 \times 10^{8}(1)$ & $8.5 \times 10^{-12}(1)$ & $7.9 \times 10^{5}(11)$ & & $3 \times 10^{3}(14)$ & - & - \\
\hline Catechol & $3.8 \times 10^{8}(4)$ & $1 \times 10^{-12}(5)$ & $8.4 \times 10^{9}(9)$ & & $8.3 \times 10^{5}(4)$ & - & - \\
\hline Phenol & $1.9 \times 10^{9}(1)$ & $1 \times 10^{-12}(5)$ & $1.9 \times 10^{9}(1)$ & $5.8 \times 10^{-12}$ & $6.47 \times 10^{2}(4)$ & - & - \\
\hline Methanol & $8.7 \times 10^{8}(1)$ & $7.7 \times 10^{-13}(1)$ & $2.07 \times 10^{5}(10)$ & - & $2.9 \times 10^{2}(12)$ & - & - \\
\hline
\end{tabular}

This cell concentration is on the same order of magnitude as found in many clouds (Amato et al., 2007c).

Experiments with 17 different cloud bacteria in artificial cloud water with $\mathrm{pH}=5.0$ and $\mathrm{pH}=6.5$ also showed nearly identical results (Vaïtilingom et al., 2011). Similar results were shown by Razika et al. (2010), who demonstrated that biodegradation rates of phenol by Pseudomonas aeruginosa were very similar when incubated at $\mathrm{pH}=5.8,7.0$, and 8.0. When exposed to very broad ranges of external $\mathrm{pH}$ values, bacteria can control their intracellular $\mathrm{pH}(\sim 6.5-7)$ by internal buffering (Delort et al., 2017). As biodegradation occurs inside the cell, it takes place at these (nearly) neutral conditions. The efficiency of buffering decreases at extreme conditions, e.g., $\mathrm{pH}<2$ or $\mathrm{pH}>10$ (Guan and Liu, 2020). However, such a $\mathrm{pH}$ range is not representative for cloud water where more moderate $\mathrm{pH}$ values $(\sim 3-6)$ are typically found (Deguillaume et al., 2014). Therefore, we do not consider a potential $\mathrm{pH}$ dependency of biodegradation rates in our model studies.

Similar to the chemical processes (Eqs. 1 and 2), we express the biological activity in terms of a rate:

$$
\begin{aligned}
R_{\text {bact }}\left[\mathrm{s}^{-1}\right] & =\frac{-\mathrm{d}(\text { Org })_{\text {bact }}}{\mathrm{d} t}=k_{\text {bact }}\left[\text { Lcell }^{-1} \mathrm{~s}^{-1}\right] \\
& \times C_{\text {cell }, \text { aq }}\left[\text { cell L }^{-1}\right]
\end{aligned}
$$

where $k_{\text {bact }}$ is the bacterial rate constant $\left[\mathrm{Lcell}^{-1} \mathrm{~s}^{-1}\right.$, and $C_{\text {cell, aq }}$ is the concentration of bacteria in cloud water [cell $\mathrm{L}^{-1}$ ]. 
Table 2. Summary of biodegradation rates from the literature and calculated rate constants $\left(k_{\text {bact }}\right)$ for the consumption of small organic species by bacteria isolated from cloud water.

\begin{tabular}{|c|c|c|c|c|c|c|c|c|c|c|}
\hline \multirow[t]{2}{*}{$\begin{array}{l}\text { Organic } \\
\text { compound }\end{array}$} & \multirow[t]{2}{*}{ Bacteria type } & \multicolumn{2}{|c|}{$\begin{array}{l}\text { Concentration in } \\
\text { the experiments }\end{array}$} & \multicolumn{2}{|c|}{$\begin{array}{l}\text { Experimental rate } \\
{\left[\mathrm{mol} \text { cell }^{-1} \mathrm{~s}^{-1}\right]}\end{array}$} & \multicolumn{2}{|c|}{$\begin{array}{c}\text { Calculated } k_{\text {bact }}^{1 \mathrm{st}} \\
{\left[\mathrm{s}^{-1}\right]}\end{array}$} & \multicolumn{2}{|c|}{$\begin{array}{l}\text { Calculated } k_{\text {bact }} \\
{\left[\text { cell }^{-1} \mathrm{Ls}^{-1}\right]}\end{array}$} & \multirow[t]{2}{*}{ Ref. } \\
\hline & & $\begin{array}{r}\text { Cells } \\
{\left[\text { cell } \mathrm{mL}^{-1}\right]}\end{array}$ & $\begin{array}{r}\text { Organic } \\
{\left[\mathrm{mol} \mathrm{L}^{-1}\right]}\end{array}$ & $17^{\circ} \mathrm{C}$ & $5^{\circ} \mathrm{C}$ & $17^{\circ} \mathrm{C}$ & $5^{\circ} \mathrm{C}$ & $17^{\circ} \mathrm{C}$ & $5^{\circ} \mathrm{C}$ & \\
\hline $\begin{array}{l}\text { Form- } \\
\text { aldehyde }\end{array}$ & $\begin{array}{l}\text { Pseudomonas graminis } \\
\text { Pseudomonas } \mathrm{sp} . \\
\text { Frigoribacterium } \mathrm{sp} . \\
\text { Bacillus } \mathrm{sp} .\end{array}$ & $8 \times 10^{4}$ & 0.02 & $\begin{array}{l}1.9 \times 10^{-20} \\
1.4 \times 10^{-19} \\
6.4 \times 10^{-21} \\
2.0 \times 10^{-20}\end{array}$ & $\begin{array}{l}8.1 \times 10^{-21} \\
8.6 \times 10^{-20} \\
6.4 \times 10^{-21} \\
3.1 \times 10^{-21}\end{array}$ & $\begin{array}{l}7.7 \times 10^{-11} \\
5.6 \times 10^{-10} \\
2.6 \times 10^{-11} \\
8.1 \times 10^{-11}\end{array}$ & $\begin{array}{l}3.2 \times 10^{-11} \\
3.4 \times 10^{-10} \\
2.6 \times 10^{-11} \\
1.2 \times 10^{-11}\end{array}$ & $\begin{array}{l}4.8 \times 10^{-18} \\
3.7 \times 10^{-17} \\
1.7 \times 10^{-18} \\
5.4 \times 10^{-18}\end{array}$ & $\begin{array}{l}2.1 \times 10^{-18} \\
2.3 \times 10^{-17} \\
1.7 \times 10^{-18} \\
8.4 \times 10^{-19}\end{array}$ & 1 \\
\hline \multirow[t]{3}{*}{ Formate } & $\begin{array}{l}\text { Sphingomonas sp. } \\
\text { Pseudomonas graminis } \\
\text { Pseudomonas sp. } \\
\text { Pseudomonas viridiflava }\end{array}$ & $10^{9}$ & 0.02 & $\begin{array}{l}9.2 \times 10^{-21} \\
1.3 \times 10^{-19} \\
4.6 \times 10^{-20} \\
1.6 \times 10^{-19} \\
\end{array}$ & $\begin{array}{l}3.1 \times 10^{-20} \\
9.6 \times 10^{-20} \\
8.6 \times 10^{-21} \\
4.7 \times 10^{-20}\end{array}$ & $\begin{array}{l}.6 \times 10^{-7} \\
6.5 \times 10^{-6} \\
2.3 \times 10^{-6} \\
8.1 \times 10^{-6} \\
\end{array}$ & $\begin{array}{l}1.6 \times 10^{-6} \\
4.8 \times 10^{-6} \\
4.3 \times 10^{-7} \\
2.3 \times 10^{-6}\end{array}$ & $\begin{array}{l}3.0 \times 10^{-14} \\
4.3 \times 10^{-13} \\
1.5 \times 10^{-13} \\
5.4 \times 10^{-13}\end{array}$ & $\begin{array}{l}1.0 \times 10^{-13} \\
3.2 \times 10^{-13} \\
2.8 \times 10^{-14} \\
1.5 \times 10^{-13}\end{array}$ & 2 \\
\hline & $\begin{array}{l}\text { Rhodococcus } \mathrm{sp} . \\
\text { Pseudomonas } \mathrm{sp} . \\
\text { Pseudomonas syringae } \\
\text { Pseudomonas graminis }\end{array}$ & $10^{6}$ & $2 \times 10^{-5}$ & $\begin{array}{l}8.0 \times 10^{-19} \\
1.5 \times 10^{-18} \\
2.3 \times 10^{-18} \\
5.0 \times 10^{-18}\end{array}$ & $\begin{array}{l}4.0 \times 10^{-19} \\
8.0 \times 10^{-19} \\
2.0 \times 10^{-18} \\
1.0 \times 10^{-18}\end{array}$ & $\begin{array}{l}4.0 \times 10^{-5} \\
7.5 \times 10^{-6} \\
1.1 \times 10^{-4} \\
2.5 \times 10^{-4}\end{array}$ & $\begin{array}{l}2.0 \times 10^{-5} \\
4.0 \times 10^{-5} \\
1.0 \times 10^{-4} \\
5.0 \times 10^{-5}\end{array}$ & $\begin{array}{l}2.6 \times 10^{-12} \\
5.0 \times 10^{-13} \\
7.3 \times 10^{-12} \\
1.6 \times 10^{-11}\end{array}$ & $\begin{array}{l}1.3 \times 10^{-12} \\
3.4 \times 10^{-13} \\
6.6 \times 10^{-12} \\
3.3 \times 10^{-12}\end{array}$ & 3 \\
\hline & $\begin{array}{l}\text { Various } \\
\text { microorganisms }\end{array}$ & $8 \times 10^{4}$ & $43 \times 10^{-6}$ & $2.1 \times 10^{-18}$ & & $4.1 \times 10^{-6}$ & & $2.7 \times 10^{-13}$ & & 4 \\
\hline \multirow[t]{3}{*}{ Acetate } & $\begin{array}{l}\text { Sphingomonas sp. } \\
\text { Pseudomonas graminis } \\
\text { Pseudomonas } \mathrm{sp} . \\
\text { Pseudomonas viridiflava }\end{array}$ & $10^{9}$ & 0.02 & $\begin{array}{l}2.7 \times 10^{-20} \\
3.0 \times 10^{-19} \\
2.6 \times 10^{-20} \\
5.6 \times 10^{-20}\end{array}$ & $\begin{array}{l}1.6 \times 10^{-22} \\
3.0 \times 10^{-20} \\
1.7 \times 10^{-20} \\
1.1 \times 10^{-20}\end{array}$ & $\begin{array}{l}1.3 \times 10^{-6} \\
1.5 \times 10^{-5} \\
1.3 \times 10^{-6} \\
2.8 \times 10^{-6}\end{array}$ & $\begin{array}{l}8.2 \times 10^{-9} \\
1.5 \times 10^{-6} \\
8.8 \times 10^{-7} \\
6.0 \times 10^{-7} \\
\end{array}$ & $\begin{array}{l}1.1 \times 10^{-13} \\
1.0 \times 10^{-12} \\
8.7 \times 10^{-14} \\
1.8 \times 10^{-13}\end{array}$ & $\begin{array}{l}5.4 \times 10^{-16} \\
1.0 \times 10^{-13} \\
5.3 \times 10^{-14} \\
4.0 \times 10^{-14}\end{array}$ & 2 \\
\hline & $\begin{array}{l}\text { Rhodococcus sp. } \\
\text { Pseudomonas sp. } \\
\text { Pseudomonas syringae } \\
\text { Pseudomonas graminis }\end{array}$ & $10^{6}$ & $2 \times 10^{-5}$ & $\begin{array}{l}5.0 \times 10^{-18} \\
1.3 \times 10^{-18} \\
8.6 \times 10^{-19} \\
4.0 \times 10^{-19}\end{array}$ & $\begin{array}{l}1.0 \times 10^{-18} \\
6.0 \times 10^{-19} \\
2.0 \times 10^{-19} \\
1.0 \times 10^{-19}\end{array}$ & $\begin{array}{l}2.5 \times 10^{-4} \\
6.7 \times 10^{-5} \\
4.3 \times 10^{-5} \\
2.0 \times 10^{-5}\end{array}$ & $\begin{array}{l}5.0 \times 10^{-5} \\
3.0 \times 10^{-5} \\
1.0 \times 10^{-5} \\
5.0 \times 10^{-6}\end{array}$ & $\begin{array}{l}1.6 \times 10^{-11} \\
4.5 \times 10^{-12} \\
2.8 \times 10^{-12} \\
1.3 \times 10^{-12}\end{array}$ & $\begin{array}{l}3.3 \times 10^{-12} \\
2.0 \times 10^{-12} \\
6.6 \times 10^{-13} \\
3.3 \times 10^{-13}\end{array}$ & 3 \\
\hline & $\begin{array}{l}\text { Various } \\
\text { microorganisms }\end{array}$ & $8 \times 10^{4}$ & $2.5 \times 10^{-6}$ & $1.94 \times 10^{-18}$ & & $6.25 \times 10^{-3}$ & & $4.16 \times 10^{-10}$ & & 4 \\
\hline \multirow[t]{3}{*}{ Succinate } & $\begin{array}{l}\text { Sphingomonas } \mathrm{sp} . \\
\text { Pseudomonas graminis } \\
\text { Pseudomonas } \mathrm{sp} . \\
\text { Pseudomonas viridiflava }\end{array}$ & $10^{9}$ & 0.02 & $\begin{array}{l}2.6 \times 10^{-20} \\
1.0 \times 10^{-19} \\
1.4 \times 10^{-20} \\
2.9 \times 10^{-20}\end{array}$ & $\begin{array}{l}1.0 \times 10^{-20} \\
9.8 \times 10^{-20} \\
1.8 \times 10^{-20} \\
6.1 \times 10^{-20}\end{array}$ & $\begin{array}{l}1.3 \times 10^{-6} \\
5.2 \times 10^{-6} \\
7.0 \times 10^{-7} \\
1.4 \times 10^{-6}\end{array}$ & $\begin{array}{l}5.4 \times 10^{-7} \\
4.9 \times 10^{-6} \\
9.2 \times 10^{-7} \\
3.0 \times 10^{-6}\end{array}$ & $\begin{array}{l}8.6 \times 10^{-14} \\
3.4 \times 10^{-13} \\
4.7 \times 10^{-14} \\
9.7 \times 10^{-14}\end{array}$ & $\begin{array}{l}3.6 \times 10^{-14} \\
3.2 \times 10^{-13} \\
6.1 \times 10^{-14} \\
2.0 \times 10^{-13}\end{array}$ & 2 \\
\hline & $\begin{array}{l}\text { Rhodococcus sp. } \\
\text { Pseudomonas sp. } \\
\text { Pseudomonas syringae } \\
\text { Pseudomonas graminis }\end{array}$ & $10^{6}$ & $2 \times 10^{-5}$ & $\begin{array}{l}5.0 \times 10^{-20} \\
1.5 \times 10^{-19} \\
6.8 \times 10^{-19} \\
5.0 \times 10^{-19}\end{array}$ & $\begin{array}{l}4.0 \times 10^{-20} \\
2.0 \times 10^{-20} \\
1.7 \times 10^{-19} \\
1.0 \times 10^{-19}\end{array}$ & $\begin{array}{l}2.5 \times 10^{-6} \\
7.5 \times 10^{-6} \\
3.4 \times 10^{-5} \\
2.5 \times 10^{-5}\end{array}$ & $\begin{array}{l}2.0 \times 10^{-6} \\
1.0 \times 10^{-6} \\
8.8 \times 10^{-6} \\
5.0 \times 10^{-6}\end{array}$ & $\begin{array}{l}1.6 \times 10^{-13} \\
5.0 \times 10^{-13} \\
2.2 \times 10^{-12} \\
1.6 \times 10^{-12}\end{array}$ & $\begin{array}{l}1.3 \times 10^{-13} \\
6.6 \times 10^{-14} \\
5.8 \times 10^{-13} \\
3.3 \times 10^{-13}\end{array}$ & 3 \\
\hline & $\begin{array}{l}\text { Various } \\
\text { microorganisms }\end{array}$ & $8 \times 10^{4}$ & $3.1 \times 10^{-6}$ & $5.6 \times 10^{-19}$ & & $1.4 \times 10^{-5}$ & & $9.6 \times 10^{-13}$ & & 4 \\
\hline Malonate & $\begin{array}{l}\text { Various } \\
\text { microorganisms }\end{array}$ & $8 \times 10^{4}$ & $3.1 \times 10^{-6}$ & $5.2 \times 10^{-19}$ & & $1.3 \times 10^{-5}$ & & $9.0 \times 10^{-13}$ & & 4 \\
\hline Catechol & Rhodococcus enclensis & $10^{7}$ & 0.0001 & $4.1 \times 10^{-19}$ & & $4.1 \times 10^{-8}$ & & $2.7 \times 10^{-15}$ & & 5 \\
\hline Phenol & Rhodococcus enclensis & $10^{9}$ & 0.0001 & $5.0 \times 10^{-20}$ & & $5.0 \times 10^{-4}$ & & $3.3 \times 10^{-11}$ & & 5 \\
\hline Methanol & $\begin{array}{l}\text { Pseudomonas graminis } \\
\text { Pseudomonas syringae } \\
\text { Frigoribacterium sp. } \\
\text { Bacillus } \mathrm{sp} .\end{array}$ & $8 \times 10^{4}$ & 0.02 & $\begin{array}{l}5.6 \times 10^{-22} \\
5.7 \times 10^{-21} \\
3.5 \times 10^{-23} \\
2.9 \times 10^{-21}\end{array}$ & $\begin{array}{r}5.8 \times 10^{-22} \\
2.5 \times 10^{-23} \\
-\end{array}$ & $\begin{array}{l}2.2 \times 10^{-12} \\
2.3 \times 10^{-11} \\
1.4 \times 10^{-13} \\
1.1 \times 10^{-11}\end{array}$ & $\begin{array}{r}2.3 \times 10^{-12} \\
1.0 \times 10^{-13} \\
-\end{array}$ & $\begin{array}{l}1.5 \times 10^{-19} \\
1.5 \times 10^{-18} \\
9.4 \times 10^{-21} \\
7.8 \times 10^{-19}\end{array}$ & $\begin{array}{r}0 \\
1.5 \times 10^{-19} \\
6.7 \times 10^{-21} \\
0\end{array}$ & 1 \\
\hline
\end{tabular}

1: Husárová et al. (2011), 2: Vaïtilingom et al. (2010), 3: Vaïtilingom et al. (2011), 4: Vaütilingom et al. (2013), 5: Jaber et al. (2020).

Several experiments showed that temperature only had a small influence on the biodegradation rates that differed at most by a factor of 2 in experiments at 5 or $17{ }^{\circ} \mathrm{C}$ (Husárová et al., 2011; Vaïtilingom et al., 2010, 2011).

\subsection{Definition of model output parameters}

\subsubsection{Relative contributions to biodegradation and chemical loss rates}

Several previous studies compared biodegradation and chemical rates in order to conclude on the potential importance of biological processes in clouds (Ariya et al., 2002; Husárová et al., 2011; Jaber et al., 2020; Vaïtilingom et al., 2011, 2013). Similarly, we define the relative contributions of the bacterial and the chemical processes in the two phases to the total loss rate of an organic compound.

$$
\begin{aligned}
& R_{\text {bact }}^{\prime}\left[\mathrm{molL}^{-1} \mathrm{~s}^{-1}\right]=R_{\text {bact }}\left[\mathrm{s}^{-1}\right] \times C_{\text {org }, \text { aq }}\left[\mathrm{mol} \mathrm{L}^{-1}\right], \\
& R_{\text {chemaq }}^{\prime}\left[\mathrm{mol} \mathrm{L}^{-1} \mathrm{~s}^{-1}\right]=R_{\text {chemaq }}\left[\mathrm{s}^{-1}\right] \times C_{\text {org, aq }}\left[\mathrm{mol} \mathrm{L}^{-1}\right],
\end{aligned}
$$


$R_{\text {chemgas }}^{\prime}\left[\mathrm{cm}^{-3} \mathrm{~s}^{-1}\right]=R_{\text {chemgas }}\left[\mathrm{s}^{-1}\right] \times C_{\text {org, gas }}\left[\mathrm{cm}^{-3}\right]$,

where $C_{\text {org,aq }}$ and $C_{\text {org,gas }}$ are the concentration of watersoluble organic gases in the aqueous $\left[\mathrm{mol} \mathrm{L}^{-1}\right]$ and gas phases $\left[\mathrm{cm}^{-3}\right]$, respectively. Their relative contributions are then expressed as

$\mathrm{fr}_{\text {bact }}[\%]=\frac{R_{\text {bact }}^{\prime}}{R_{\text {bact }}^{\prime}+R_{\text {chemaq }}^{\prime}+R_{\text {chemgas }}^{\prime}} \times 100$,

$\mathrm{fr}_{\text {chemaq }}[\%]=\frac{R_{\text {chemaq }}^{\prime}}{R_{\text {bact }}^{\prime}+R_{\text {chemaq }}^{\prime}+R_{\text {chemgas }}^{\prime}} \times 100$,

$\mathrm{fr}_{\text {chemgas }}[\%]=\frac{R_{\text {chemgas }}^{\prime}}{R_{\text {bact }}^{\prime}+R_{\text {chemaq }}^{\prime}+R_{\text {chemgas }}^{\prime}} \times 100$,

where these fractions always add up to $100 \%$. As $\mathrm{CCN}$-derived compounds are only in the aqueous phase, $\mathrm{fr}_{\text {chemgas, }} \mathrm{CCN}$-derived $=0$.

\subsubsection{Contributions to total loss of organics by bacterial and chemical processes}

While $\mathrm{fr}_{\text {bact }}, \mathrm{fr}_{\text {chemaq }}$, and $\mathrm{fr}_{\text {chemgas }}$ define the relative importance of the bacterial and chemical loss rates, they do not give quantitative information on the total loss of the organics. To define this sink strength, we introduce the parameter $L_{\mathrm{t}}[\%]$ as

$$
\begin{aligned}
L_{\mathrm{t}}[\%] & =100-\left[\frac{[\mathrm{Org}]_{\mathrm{t}}}{[\mathrm{Org}]_{0}} \times 100\right] \\
& =L_{\text {bact }}+L_{\text {chemaq }}+L_{\text {chemgas }},
\end{aligned}
$$

where $[\mathrm{Org}]_{0}$ is the initial organic concentration $(1 \mathrm{ppb})$ and [Org $]_{\mathrm{t}}$ is the organic concentration at time $t$ (for most simulations: $t=600 \mathrm{~s}$ ). Accordingly, $L_{\text {bact }}, L_{\text {chemaq }}$ and $L_{\text {chemgas }}$ are the fractions [\%] of organics consumed by bacteria and radicals in the aqueous and gas phases, respectively.

$$
\begin{aligned}
& L_{\text {bact }}[\%]=\operatorname{fr}_{\text {bact }}[\%] \times L_{\mathrm{t}}[\%] \div 100 \%, \\
& L_{\text {chemaq }}[\%]=\operatorname{fr}_{\text {chemaq }}[\%] \times L_{\mathrm{t}}[\%] \div 100 \%, \\
& L_{\text {chemgas }}[\%]=\operatorname{fr}_{\text {chemgas }}[\%] \times L_{\mathrm{t}}[\%] \div 100 \% .
\end{aligned}
$$

As both the fractions "fr" and $L$ are expressed in percent, we divided by $100 \%$ in Eqs. (11)-(13). Unlike the sum of $\mathrm{fr}_{\text {bact }}$, $\mathrm{fr}_{\text {chemaq }}$, and $\mathrm{fr}_{\text {chemgas }}$ that always yields $100 \%$ (Eqs. 7-9), by definition $L_{\mathrm{t}}$ does not have to reach $100 \%$. As we only consider one cloud cycle in our simulations $(t=600 \mathrm{~s})$, the values of $L_{\mathrm{t}}, L_{\text {bact }}, L_{\text {chemgas}}$, and $L_{\text {chemaq }}$ are rather small (a few percent at most); however, it should be kept in mind that particles likely undergo multiple cloud cycles during their residence time in the atmosphere. Thus, the contribution of chemical and biological processes to the total loss for a specific organic species can be extrapolated for longer timescales based on our results. However, as one of the main goals of our study is to compare biodegradation to the better constrained chemical losses, our conclusions will be independent of the timescales.

\section{Results and discussion}

\subsection{Relative loss rate of organics by biological processes $\left(\mathbf{f r}_{\text {bact }}\right)$}

\subsection{1 $\operatorname{fr}_{\text {bact }}$ of water-soluble organic gases}

We first compare the contributions of biodegradation and chemical losses to the total loss rate for water-soluble organic gases. In order to cover a representative parameter range of the physicochemical properties of the organic compound, we performed five simulations in which the full ranges of $K_{\mathrm{H}}$ and of $R_{\text {chemaq }}$ over 8 orders of magnitude were explored (Sect. 2.2). The simulations differ by the assumptions of $R_{\text {chemgas }}$ and $R_{\text {bact }}$ that are kept constant in the individual model runs. For the results shown in Fig. 2a, b, and c, we applied $R_{\text {bact }}=10^{-8}, 10^{-6}$, and $10^{-4} \mathrm{~s}^{-1}$ and $R_{\text {chemgas }}=10^{-6} \mathrm{~s}^{-1}$, respectively. For the three sets of simulations shown in Fig. 2b, d, and e, $R_{\text {bact }}=10^{-6} \mathrm{~s}^{-1}$ and $R_{\text {chemgas }}$ equal to $10^{-6}, 10^{-5}$, and $10^{-4} \mathrm{~s}^{-1}$ were assumed. Thus, in total three values each for $R_{\text {chemgas }}$ and $R_{\text {bact }}$ are discussed in the following.

In general, for all combinations of $R_{\text {chemgas }}$ and $R_{\text {bact }}$, the highest $\mathrm{fr}_{\text {bact }}$ is predicted for organics with the highest solubility $\left(K_{\mathrm{H}}\left[\mathrm{M} \mathrm{atm}^{-1}\right] \geq 10^{8}\right)$ and lowest chemical reaction rate in the aqueous phase $\left(R_{\text {chemaq }}\left[\mathrm{s}^{-1}\right] \leq 10^{-11}\right)$. For the lowest biological activity $\left(R_{\text {bact }}=10^{-8} \mathrm{~s}^{-1}\right.$, Fig. 2a), fr bact reaches a maximum value of $\sim 100 \%$. For higher biological activity $\left(R_{\text {bact }}=10^{-6}\right.$ and $\left.10^{-4} \mathrm{~s}^{-1}\right)$, fr bact $_{\text {bat }}$ always smaller and only reaches at most $\sim 80 \%$ (Fig. $2 \mathrm{~b}$ and c). This trend seems counterintuitive as for the highest $R_{\text {bact }}$ the highest importance of biodegradation may be expected. We will explore the reasons for this further in Sect. 3.1.2 where we compare loss rates in individual droplets as a function of time.

The comparison of Fig. $2 b$ and $c$ shows that the parameter ranges, for which $\mathrm{fr}_{\text {bact }}$ has the maximum value, are broader for higher $R_{\text {bact }}$ : when $R_{\text {bact }}=10^{-6} \mathrm{~s}^{-1}$ (Fig. 2b), fr $\mathrm{r}_{\text {bact }}$ is $\sim 80 \%$ within the ranges of $\sim 10^{7} \leq K_{\mathrm{H}}\left[\mathrm{M} \mathrm{atm}^{-1}\right] \leq \sim 10^{9}$ and $10^{-12} \leq R_{\text {chemaq }}\left[\mathrm{s}^{-1}\right] \leq 10^{-10}$; i.e., both $R_{\text {chemaq }}$ and $K_{\mathrm{H}}$ span about 2 orders of magnitude. For $R_{\text {bact }}=10^{-4} \mathrm{~s}^{-1}$ (Fig. 2c), these ranges are $\sim 10^{5} \leq K_{\mathrm{H}}\left[\mathrm{M} \mathrm{atm}^{-1}\right] \leq \sim 10^{9}$ and $\left.10^{-12} \leq R_{\text {chemaq }} \mathrm{s}^{-1}\right] \leq 10^{-9}$, i.e., wider by about 2 and 1 orders of magnitude, respectively.

This widening of the parameter space can be explained by the contributions of the chemical processes to the total organic loss rate, i.e., $\mathrm{fr}_{\text {chemaq }}$ and $\mathrm{fr}_{\text {chemgas }}$ (Figs. S1 and S2 in the Supplement); for the two values of $R_{\text {bact }}, \mathrm{fr}_{\text {chemaq }}$ is highest $\left(>80 \%\right.$ ) for a combination of (i) $\sim 10^{5} \leq K_{\mathrm{H}}\left[\mathrm{M} \mathrm{atm}^{-1}\right]$ $\leq 10^{9}$ and $\sim 10^{-9} \leq R_{\text {chemaq }}\left[\mathrm{s}^{-1}\right] \leq 10^{-\overline{5}}$, or of (ii) low or intermediate solubility $\left(\sim 10^{3} \leq K_{\mathrm{H}}\left[\mathrm{Matm}^{-1}\right] \leq \sim 10^{5}\right)$ and high chemical aqueous-phase reactivity $\left(10^{-6} \leq R_{\text {chemaq }}\right.$ $\left.\left[\mathrm{s}^{-1}\right] \leq 10^{-5}\right)$. These trends are due to the predominant partitioning of highly soluble organics to the aqueous phase ( $>$ $90 \%$ for $K_{\mathrm{H}} \geq 10^{6} \mathrm{M} \mathrm{atm}^{-1}$ ). If $R_{\text {chemaq }}$ is low, the organics do not undergo efficient chemical processes in the aqueous 

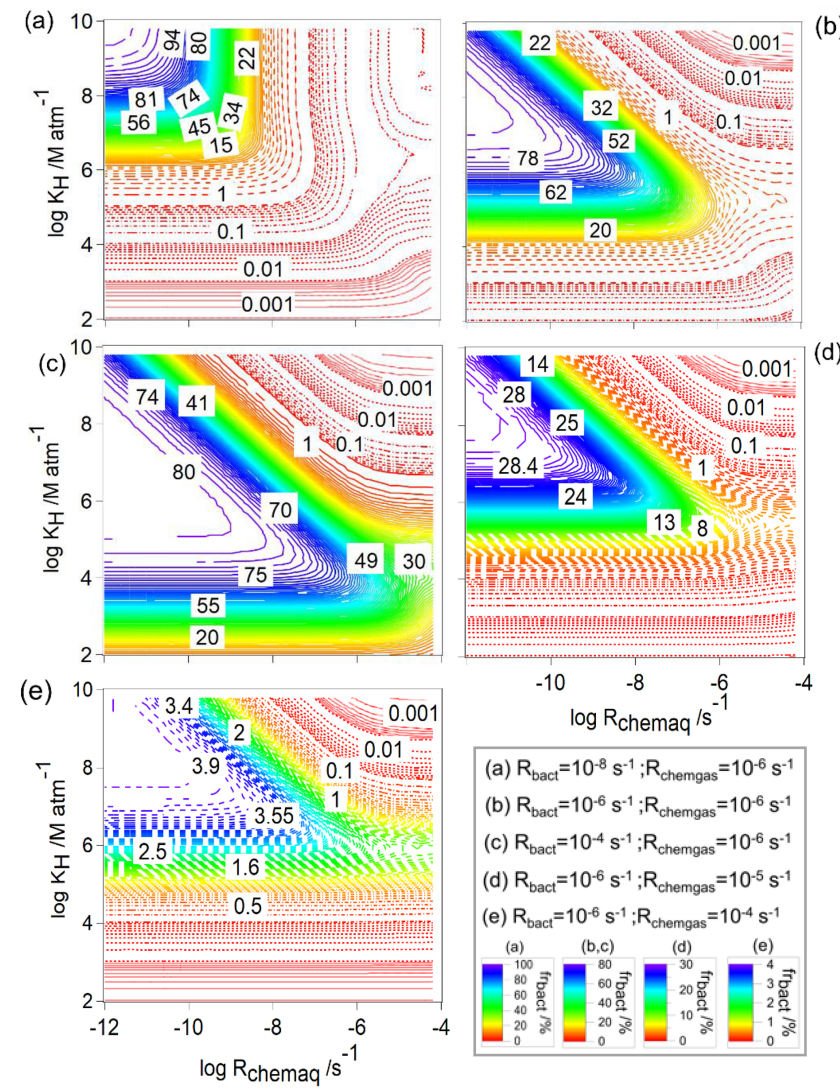

(a) $R_{\text {bact }}=10^{-8} \mathrm{~s}^{-1} ; R_{\text {chemgas }}=10^{-6} \mathrm{~s}^{-1}$ (b) $R_{\text {bact }}=10^{-6} \mathrm{~s}^{-1} ; R_{\text {chemgas }}=10^{-6} \mathrm{~s}^{-1}$ (c) $R_{\text {bact }}=10^{-4} \mathrm{~s}^{-1} ; R_{\text {chemgas }}=10^{-6} \mathrm{~s}^{-1}$ (d) $R_{\text {bact }}=10^{-6} \mathrm{~s}^{-1} ; R_{\text {chemgas }}=10^{-5} \mathrm{~s}^{-1}$ (e) $R_{\text {bact }}=10^{-6} \mathrm{~s}^{-1} ; R_{\text {chemgas }}=10^{-4} \mathrm{~s}^{-1}$

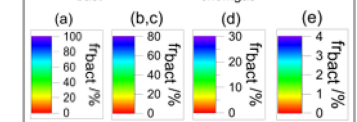

Figure 2. Relative contribution of bacteria to the total loss rate of organics (fr $\left.\mathrm{fract}_{\text {bat }}, \mathrm{Eq} .7\right)$ as a function of $R_{\text {chemaq }}$ and $K_{\mathrm{H}}$. All figure panels have the same scales on the ordinates and abscissas. The simulations were performed for constant values of $R_{\text {bact }}$ and $R_{\text {chemgas }}$; their values are indicated in the box at the bottom right.

phase. Therefore, $\mathrm{fr}_{\text {bact }}$ is highest for this parameter combination. The comparison of the results for $R_{\text {bact }}=10^{-6} \mathrm{~s}^{-1}$ and three values of $R_{\text {chemgas }}$ (Fig. $2 \mathrm{~b}, \mathrm{~d}$, e) shows a decrease in the maximum value of fr $_{\text {bact }}$ from $80 \%$ (Fig. 2 b) to $4 \%$ (Fig. 2e) for similar ranges of $K_{\mathrm{H}}$ and $R_{\text {chemaq }}$ because of the dependence of $\mathrm{fr}_{\text {bact }}$ on $\mathrm{fr}_{\text {chemgas }}$ : for compounds with highest $R_{\text {chemgas }}$, the dominant loss is the gas-phase reaction, leading to a high $\mathrm{fr}_{\text {chemgas }}$ and consequently to a lower $\mathrm{fr}_{\text {bact }}$ (Fig. 2e). Therefore, the parameter ranges of $K_{\mathrm{H}}$ and $R_{\text {chemaq }}$, where $\mathrm{fr}_{\text {bact }}$ is maximum, do not change for different $R_{\text {chemgas }}$ but decrease when the gas-phase chemistry dominates the loss of the organic species.

Overall, the variation in $\mathrm{fr}_{\text {bact }}$ as a response to changes in $R_{\text {chemaq }}, R_{\text {chemgas }}$, and $K_{\mathrm{H}}$ shows different sensitivities: for example, for organics with $K_{\mathrm{H}}=10^{6} \mathrm{M} \mathrm{atm}^{-1}, R_{\text {chemaq }}=$ $10^{-9} \mathrm{~s}^{-1}$, and $R_{\text {chemgas }}=10^{-6} \mathrm{~s}^{-1}$, fr fact $_{\text {bact }}$ is $\sim 8 \%$ when $R_{\text {bact }}=10^{-8} \mathrm{~s}^{-1}$ (red area in Fig. 2a). This fraction increases to fr bact $\sim 73 \%$, i.e., by a factor of $\sim 9$, when $R_{\text {bact }}=$ $10^{-6} \mathrm{~s}^{-1}$ (blue area in Fig. 2b) and approaches $\sim 80 \%$ when $R_{\text {bact }}=10^{-4} \mathrm{~s}^{-1}$ (purple area in Fig. 2c). Similarly, for organics with $K_{\mathrm{H}} \sim 10^{6} \mathrm{Matm}^{-1}, R_{\text {chemaq }}=10^{-9} \mathrm{~s}^{-1}$,

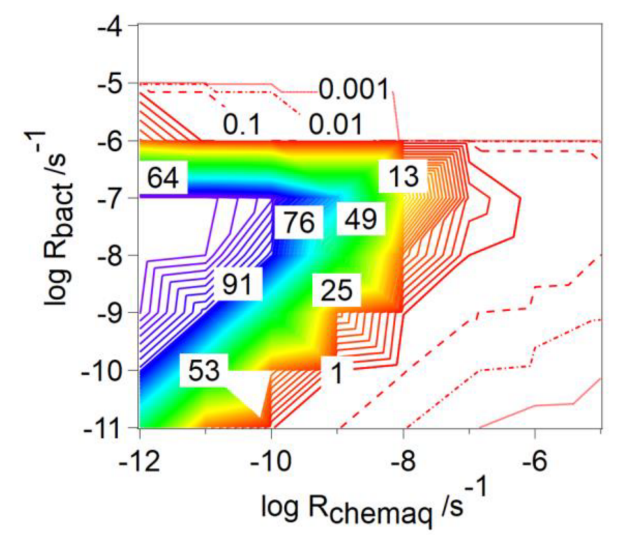

Figure 3. Relative contribution of bacteria to the total loss rate of CCN-derived organics (fr $\mathrm{fract}_{\text {bat }}$, Eq. 7) as a function of $R_{\text {bact }}\left[\mathrm{s}^{-1}\right]$ and $R_{\text {chemaq }}{ }^{\left[\mathrm{s}^{-1}\right.}$.

and $R_{\text {bact }}=10^{-6} \mathrm{~s}^{-1}$, an increase in $R_{\text {chemgas }}$ from $10^{-6} \mathrm{~s}^{-1}$ (Fig. 2b) to $10^{-5} \mathrm{~s}^{-1}$ (Fig. 2d) and $10^{-4} \mathrm{~s}^{-1}$ (Fig. 2e) decreases fr bact $_{\text {brom }} 73 \%$ to $23 \%$ and $3 \%$, respectively. Based on these nonlinear trends, one can hypothesize that (i) a change in $R_{\text {bact }}$ and/or $R_{\text {chemgas }}$ translates into a less than proportional change in $\mathrm{fr}_{\text {bact }}$, and (ii) an increase in $R_{\text {bact }}$ might translate into a larger change in fr bact than an increase in $R_{\text {chemgas }}$ by the same factor. Therefore, $\mathrm{fr}_{\text {bact }}$ is more sensitive to a change in $R_{\text {bact }}$ than in $R_{\text {chemgas }}$. Given that $R_{\text {chemgas }}$ only differs by about 2 orders of magnitude for most organics relevant in the atmospheric multiphase system (Table 1), we conclude that $\mathrm{fr}_{\text {bact }}$ may be largely independent of the gasphase chemical reactivity. Additional sensitivity studies (not shown) reveal that using combinations of $R_{\text {bact }}$ and $R_{\text {chemgas }}$ other than those in Fig. 2 result in slightly different locations of the maximum of $\mathrm{fr}_{\text {bact }}$ but in similar shapes and widths of parameter spaces, for which $\mathrm{fr}_{\text {bact }}$ is maximum. Therefore, our conclusions on the sensitivities seem robust for wide parameter ranges and combinations.

\subsection{2 fr bact of CCN-derived compounds and comparison to water-soluble organic gases}

For CCN-derived compounds, the analysis of fr bact is limited to exploring the ranges of $R_{\text {bact }}$ and $R_{\text {chemaq }}$ (Fig. 1). Similar to the findings based on Fig. 2a, b, and c for watersoluble organic gases, highest values of $\mathrm{fr}_{\text {bact }}$ are predicted for intermediate values of $10^{-10} \leq R_{\text {bact }}\left[\mathrm{s}^{-1}\right] \leq 10^{-7}$ and $R_{\text {chemaq }}\left[\mathrm{s}^{-1}\right] \leq 10^{-10}$; for the highest biological activity $\left(R_{\text {bact }}=10^{-4} \mathrm{~s}^{-1}\right)$, fr bact is nearly zero (Fig. 3 ). In order to understand the reasons for these trends, we explore in the following the variables determining fr $_{\text {bact }}$ (Eq. 7).

As shown in Fig. 1, only one drop size class in the model contains bacteria; in all other droplets, the bacterial activity is zero, and only chemical processes occur. In Fig. 4a, we show the evolution of the organic concentration of $\mathrm{CCN}$-derived compounds in the bacteria-containing droplets ([Org $]_{\text {bact }}$ ) 
over $600 \mathrm{~s}, R_{\text {chemaq }}=10^{-11} \mathrm{~s}^{-1}$, and $R_{\text {chemgas }}=10^{-6} \mathrm{~s}^{-1}$, i.e., for relatively low chemical reactivity in both phases. It is obvious that for the highest $R_{\text {bact }}\left(10^{-4} \mathrm{~s}^{-1}\right)$, the organics are immediately depleted, whereas for lower biological activity $\left(R_{\text {bact }}=10^{-6} \mathrm{~s}^{-1}\right),[\mathrm{Org}]_{\text {bact }}$ decreases more slowly or even stays constant $\left(R_{\text {bact }}=10^{-8} \mathrm{~s}^{-1}\right)$. As for the highest $R_{\text {bact }}$, the concentration approaches zero after $\sim 10 \mathrm{~s}$, $R_{\text {bact }}^{\prime}$ (Eq. 4) becomes negligible and fr bact approaches $0 \%$ (Eq. 7, Fig. 4c). In Fig. 4b, we show the equivalent to Fig. 4a but for water-soluble organic gases and for three $K_{\mathrm{H}}$ values $\left(10^{2}, 10^{5}\right.$, and $\left.10^{9} \mathrm{M} \mathrm{atm}^{-1}\right)$. For the lowest $R_{\text {bact }}$ and all $K_{\mathrm{H}}$ values, [Org] $]_{\text {bact }}$ stays also nearly constant at the initial value as the organics are not efficiently consumed in any droplet. For the intermediate and highest $R_{\text {bact }}\left(10^{-6}\right.$ and $10^{-4} \mathrm{~s}^{-1}$ ) and $K_{\mathrm{H}}=10^{9} \mathrm{M} \mathrm{atm}^{-1}$, [Org] bact remains higher than for the $\mathrm{CCN}$-derived compounds and levels off at $t \sim 300 \mathrm{~s}$. For these two, $R_{\text {bact }}$, $[\mathrm{Org}]_{\text {bact }}$ significantly drops by several orders of magnitude. However, unlike for the $\mathrm{CCN}$-derived compounds, $\mathrm{fr}_{\text {bact }}$ does not drop to $\sim 0 \%$ but levels off at $\sim 70 \%$ for $K_{\mathrm{H}}=10^{9} \mathrm{Matm}^{-1}$ (Fig. 4 d). For these two $R_{\text {bact }}$ and $K_{\mathrm{H}}=10^{5} \mathrm{M} \mathrm{atm}^{-1}$, [Org] bact stays also nearly constant over the whole simulation time $(600 \mathrm{~s})$ and is higher for lowest $R_{\text {bact }}=10^{-6} \mathrm{~s}^{-1}$ (Fig. $4 \mathrm{~b}$ ). However, fr $_{\text {bact }}$ is higher for the highest $R_{\text {bact }}=10^{-4} \mathrm{~s}^{-1}$ (Fig. 4d). Fig. S3a and b show the ratio of the organic concentrations in bacteria-containing and bacteria-free droplets of the same diameter $(20 \mu \mathrm{m})$. For these conditions of low $R_{\text {chemgas }}$ and $R_{\text {chemaq }}$, the concentration ratio is near unity for both $\mathrm{CCN}$-derived compounds and water-soluble organic gases $\left(K_{\mathrm{H}}=10^{5}\right.$ and $10^{9} \mathrm{M} \mathrm{atm}^{-1}$ ) when $R_{\text {bact }}=10^{-8} \mathrm{~s}^{-1}$. For higher $R_{\text {bact }}=10^{-6} \mathrm{~s}^{-1}$ and $K_{\mathrm{H}}=10^{5}$ and $10^{9} \mathrm{M} \mathrm{atm}^{-1}$, the concentration ratio for the water-soluble organic gases is near unity and $10^{-3}$, respectively, and for the $\mathrm{CCN}$-derived compounds it is much lower $\left(\sim 10^{-6}\right)$. For $R_{\text {bact }}=10^{-4} \mathrm{~s}^{-1}$, this ratio is also higher for $K_{\mathrm{H}}=10^{5} \mathrm{M} \mathrm{atm}^{-1}$ than for $K_{\mathrm{H}}=10^{9} \mathrm{M} \mathrm{atm}^{-1}\left(\sim 10^{-1}\right.$ and $10^{-5}$, respectively $)$ and $\ll$ $10^{-11}$ for CCN-derived compounds. It can be summarized that (1) for water-soluble organic gases the concentration in bacteria-containing droplets is higher for compounds with intermediate solubility $\left(K_{\mathrm{H}} \sim 10^{5} \mathrm{M} \mathrm{atm}^{-1}\right)$ than for highly soluble ones $\left(K_{\mathrm{H}}=10^{9} \mathrm{Matm}^{-1}\right)$, and (2) the concentration in bacteria-containing droplets is predicted to be always smaller for the $\mathrm{CCN}$-derived compounds than for the watersoluble organic gases with at least intermediate solubility.

This difference between water-soluble organic gases and $\mathrm{CCN}$-derived compounds can be explained by the schematic in Fig. 5: the insets in the droplets schematically depict the temporal evolution of the organic concentrations as shown in Fig. 4. The efficient consumption of organics by bacteria in the bacteria-containing droplets (I) leads to a significant decrease in the organic concentration in these droplets. For water-soluble organic gases, this results in a strong deviation from thermodynamic equilibrium of the gas- and aqueousphase concentrations, as defined by Henry's law (II). As a consequence, organics diffuse from the gas phase into the bacteria-containing droplets (III). As this diffusion leads to a decrease in the gas-phase concentration, thermodynamic equilibrium between the gas phase and the bacteria-free droplets is not fulfilled anymore (IV), resulting in a concentration gradient between these droplets and the gas phase. Finally, organics from the bacteria-free droplets evaporate to replenish the gas-phase concentration $(\mathrm{V})$ and eventually the organic concentration in the bacteria-containing droplets. These coupled equilibria between the gas phase and droplets lead to a continuous replenishment of water-soluble organic gases in the bacteria-containing droplets. However, since all processes are associated with different timescales (evaporation, gas-phase diffusion, transport through the gas / water interface, loss by chemical and biological processes in the aqueous phase; Schwartz, 1986), thermodynamic equilibrium is not instantaneously established. For organics with low $K_{\mathrm{H}}\left(\sim 10^{2} \mathrm{M} \mathrm{atm}^{-1}\right)$, the fraction of dissolved material is very small; therefore, organics are mostly consumed in the gas phase and only a small fraction partitions to the droplets. For intermediate $K_{\mathrm{H}}\left(\sim 10^{5} \mathrm{M} \mathrm{atm}^{-1}\right)$, the consumption of the organics in the bacteria-containing droplets is fast, leading to large concentration gradients between the phases. Consequently, the evaporation and diffusion rates are high; thus, the replenishment of the bacteria-containing droplets by the organics is most efficient. Extremely highly soluble organics $\left(K_{\mathrm{H}} \sim 10^{9} \mathrm{M} \mathrm{atm}^{-1}\right)$ are nearly completely dissolved in the aqueous phase; thus, only a small fraction will be consumed by the bacteria, leading to relatively smaller concentration gradients between gas and bacteria-containing droplets (process I and Fig. 4b) and therefore to less efficient replenishment and longer timescales to establish thermodynamic equilibrium. Thus for such organics, the organic consumption by bacteria is relatively less efficient. For $\mathrm{CCN}$-derived compounds, only process I occurs as there is no coupling to the gas phase; thus, only the amount of organics that is initially dissolved in the bacteria-containing droplets can be consumed.

\subsection{Total loss of the organic compound $\left(L_{t}\right)$ and sinks of organics by bacteria $\left(L_{\text {bact }}\right)$}

\subsection{1 $L_{\mathrm{t}}$ for water-soluble organic gases}

While the analysis of $\mathrm{fr}_{\text {bact }}$ in Sect. 3.1 quantifies the relative importance of the biological and chemical processes for the organic loss, we explore in the following the absolute loss of these processes $\left(L_{\mathrm{t}}\right.$, Eq. 10$)$.

Unlike the sum of $\mathrm{fr}_{\text {bact }}, \mathrm{fr}_{\text {chemaq }}$, and $\mathrm{fr}_{\text {chemgas }}$ that always yields $100 \%$, the ranges of $L_{\mathrm{t}}$ that will be discussed in the following are rather small, i.e., $10^{-4} \leq L_{\mathrm{t}}[\%] \leq 12$, given that we only simulate approximately one cloud cycle $(600 \mathrm{~s})$. Figure 6 shows $L_{\mathrm{t}}$ for the same parameters ( $\left.R_{\text {chemgas }}, R_{\text {bact }}\right)$ as in Fig. 2. For all combinations of $R_{\text {bact }}$ and $R_{\text {chemgas }}$, the highest values of $L_{\mathrm{t}}$ are predicted for organics with highest $K_{\mathrm{H}}$ and $R_{\text {chemaq. }}$. Generally, all panels show the highest val- 

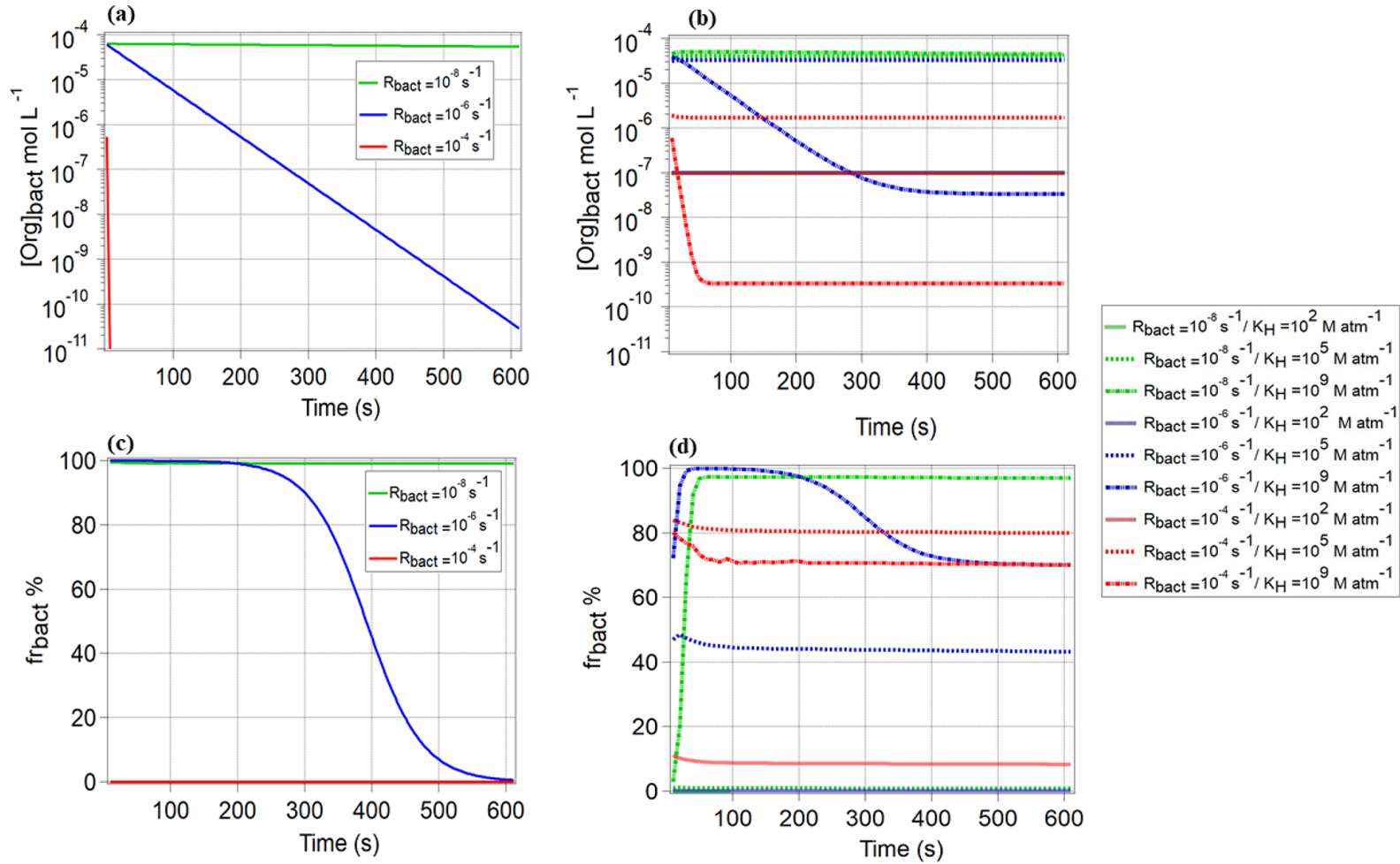

Figure 4. Comparison of the organic concentration in the bacteria-containing droplets $[\mathrm{Org}]_{\text {bact }}\left[\mathrm{mol} \mathrm{L}^{-1}\right]$ for (a) CCN-derived compounds, (b) water-soluble organic gases $\left(K_{\mathrm{H}}=10^{2}, 10^{5}\right.$ and $\left.10^{9} \mathrm{M} \mathrm{atm}^{-1}\right)$, and $(\mathbf{c}, \mathbf{d})$ the resulting fr $\mathrm{f}_{\text {bact }}$ for these compounds. Results are shown for $R_{\text {bact }}=10^{-8}, 10^{-6}$, and $10^{-4} \mathrm{~s}^{-1} ; R_{\text {chemgas }}=10^{-6} \mathrm{~s}^{-1}$; and $R_{\text {chemaq }}=10^{-11} \mathrm{~s}^{-1}$.

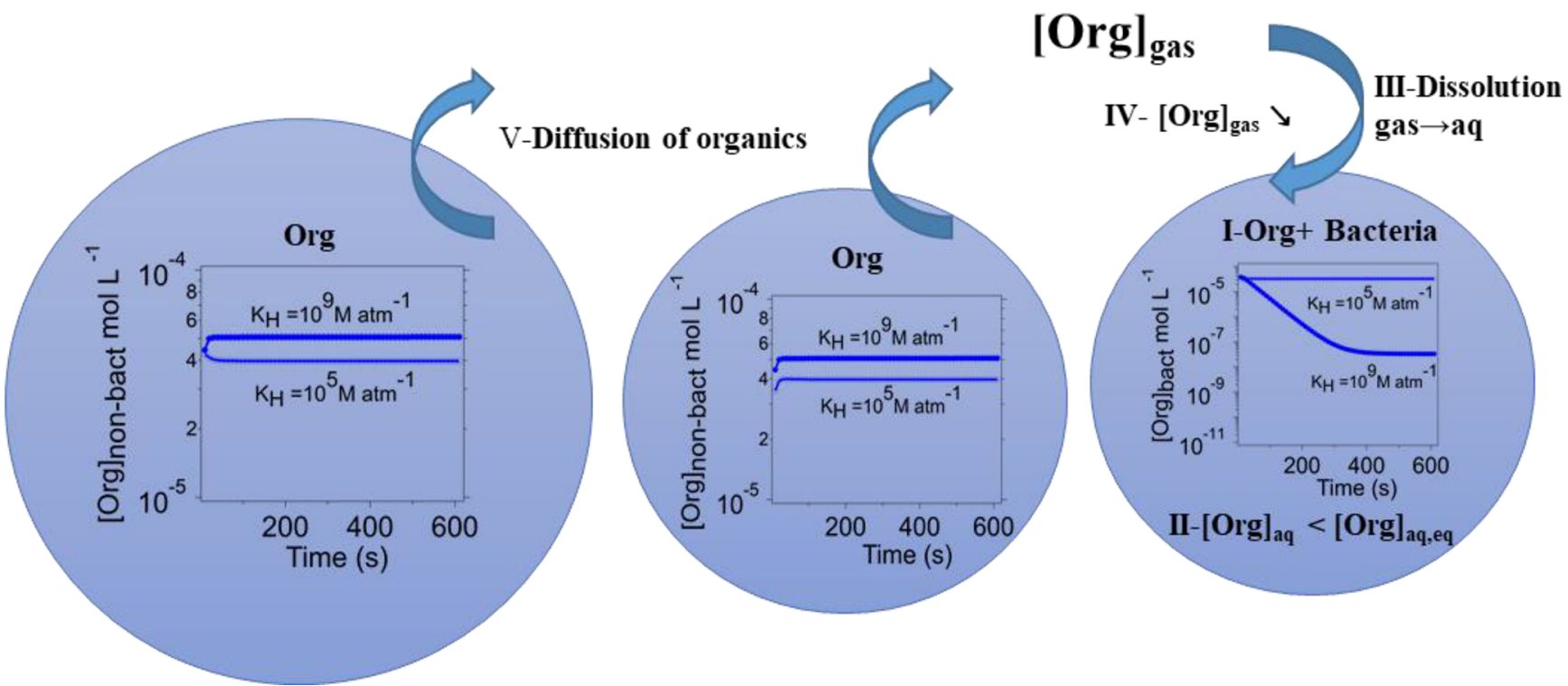

Figure 5. Schematic of the partitioning of water-soluble organic gases between the bacteria-containing and bacteria-free droplets and the gas phase: the inset figures show the temporal evolution of the organic concentration in the bacteria-containing droplets ([Org $\left.]_{\text {bact }}\right)$ and bacteria-free droplets ([Org $]_{\text {non-bact }}$ ) for water-soluble organic gases with $K_{\mathrm{H}}=10^{5}$ and $10^{9} \mathrm{M} \mathrm{atm}^{-1}$. 

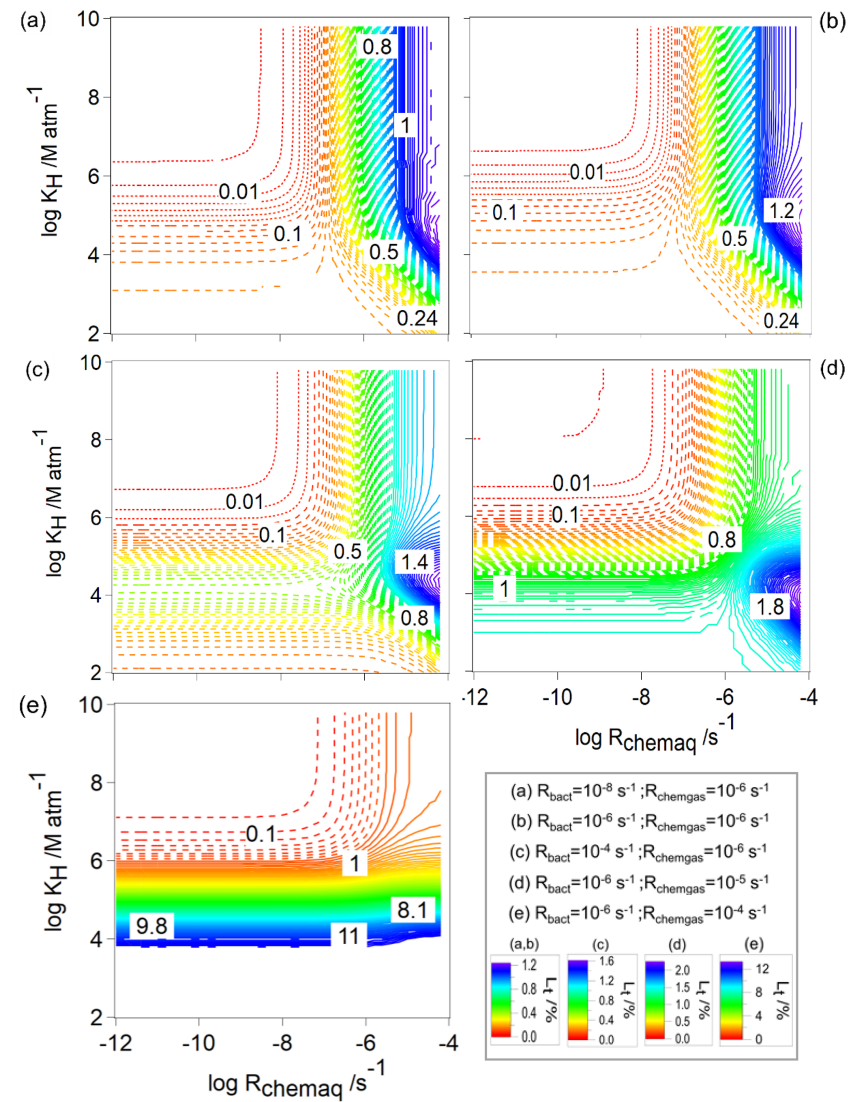

Figure 6. The total loss of water-soluble organic gases $\left(L_{\mathrm{t}}\right.$, Eq. 10) as a function of $R_{\text {chemaq }}$ and $K_{\mathrm{H}}$. All figure panels have the same scales on the ordinates and abscissas. The simulations were performed for constant values of $R_{\text {bact }}$ and $R_{\text {chemgas }}$; their values are indicated in the box at the bottom right.

ues for $L_{\mathrm{t}}$ for the highest $R_{\text {chemaq }}$, but in all panels there is a small maximum for low-to-intermediate $K_{\mathrm{H}}$ and nearly independent of $R_{\text {chemaq. }}$. This feature becomes more prominent with increasing $R_{\text {chemgas }}\left(10^{-6}, 10^{-5}, 10^{-4} \mathrm{~s}^{-1}\right.$, Fig. 6c-e), with the overall highest $L_{\mathrm{t}}(\sim 12 \%)$ for the highest $R_{\text {chemgas }}$ and lowest $K_{\mathrm{H}}$. Comparing Fig. 6a, b, and c, for which the model conditions only differ in $R_{\text {bact }}$, a small increase in $L_{\mathrm{t}}$ from $1.2 \%$ to $1.6 \%$ at intermediate $K_{\mathrm{H}}$ values can be seen. We focus on these trends in Sect. 3.2.2 where $L_{\text {bact }}$, i.e., the contribution of the bacterial process to $L_{\mathrm{t}}$, will be explored. Comparing the contours of the three panels shows that $L_{\mathrm{t}}$ is additive as with increasing $R_{\text {bact }}, L_{\mathrm{t}}$ reaches a maximum $(1.6 \%)$ at $K_{\mathrm{H}}$ of $\sim 10^{4} \mathrm{M} \mathrm{atm}^{-1}$, and $R_{\text {chemaq }}$ is $\sim 10^{-5} \mathrm{~s}^{-1}$ (Fig. 6c). Similar to our findings for fr bact $_{\text {bect. 3.1.1), we }}$ also see in the trends of $L_{\mathrm{t}}$ that a change of several orders of magnitude in $R_{\text {bact }}$ or $R_{\text {chemgas }}$ translates into a smaller change in $L_{\mathrm{t}}$. Thus, one can conclude that $L_{\mathrm{t}}$ has a similarly low sensitivity to the various parameters as fr bact.
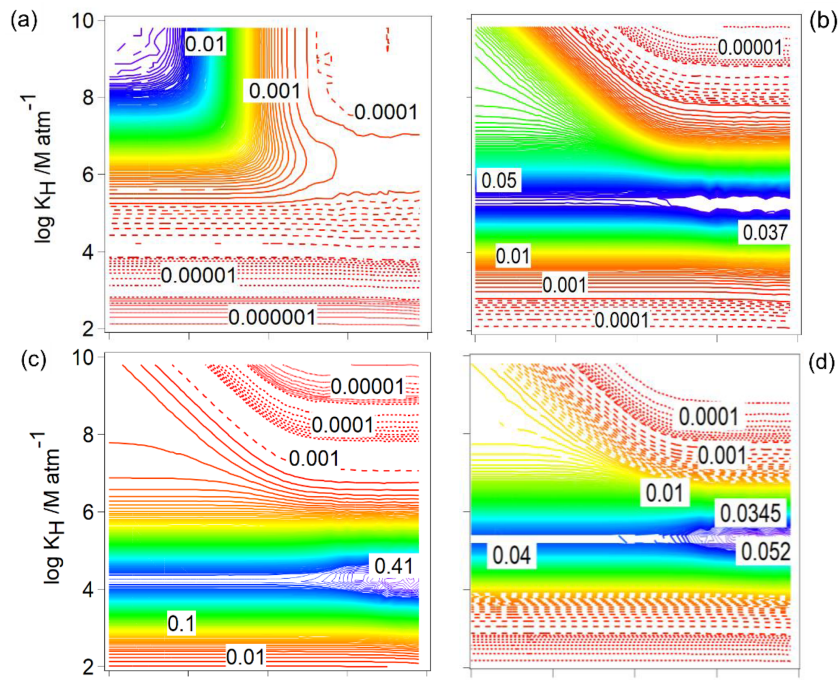

(e)
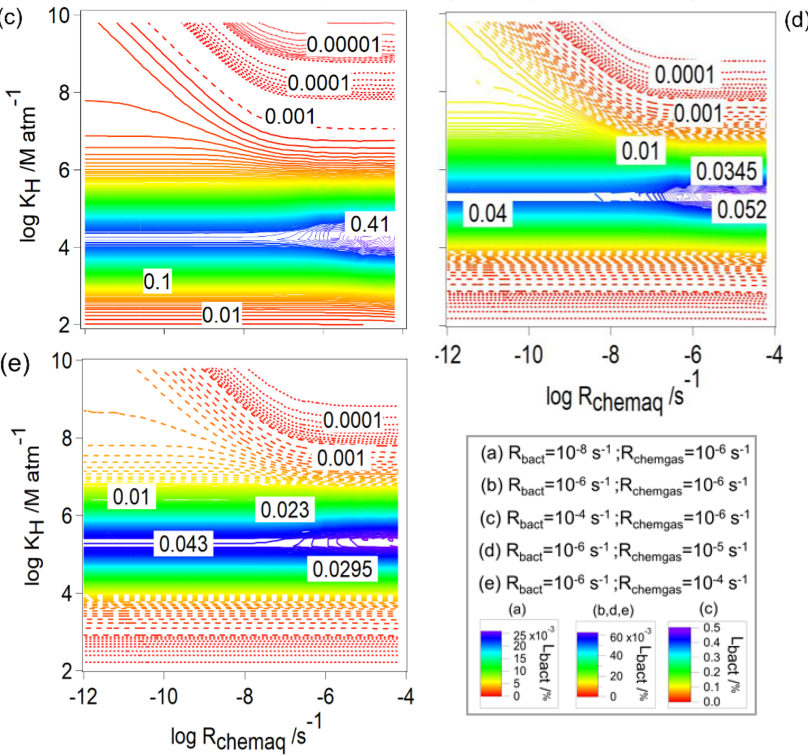

(d)

Figure 7. The loss of water-soluble organic gases by bacteria $\left(L_{\text {bact }}\right.$, Eq. 11) as a function of $R_{\text {chemaq }}$ and $K_{\mathrm{H}}$. All figure panels have the same scales on the ordinates and abscissas. The simulations were performed for constant values of $R_{\text {bact }}$ and $R_{\text {chemgas }}$; their values are indicated in the box at the bottom right.

\subsection{2 $L_{\text {bact }}$ for water-soluble organic gases}

To understand the contribution of bacteria $\left(L_{\text {bact }}\right)$ in the total consumption of the organics $\left(L_{\mathrm{t}}\right)$, we explore $L_{\text {bact }}$ for the same values of $R_{\text {bact }}$ and $R_{\text {chemgas }}$ as in Figs. 2 and 6 (Fig. 7). As suggested in the comparison of Fig. 6a-c, the contribution of the organic loss by bacteria increases with increasing $R_{\text {bact }}$ (Fig. 7 a-c); i.e., $L_{\text {bact }}$ increases from $0.025 \%$ to $0.45 \%$.

For all conditions, there is a contribution of $L_{\text {bact }} \sim$ $0.025 \%$ for the lowest $R_{\text {chemaq }}$ and highest $K_{\mathrm{H}}$, i.e., when chemical activity in the aqueous phase is lowest and solubility is highest. However, when $R_{\text {bact }} \geq 10^{-6} \mathrm{~s}^{-1}$, the maximum value of $L_{\text {bact }}$ is predicted for a narrow range of $\sim$ $10^{4} \leq K_{\mathrm{H}}\left[\mathrm{M} \mathrm{atm}^{-1}\right] \leq 10^{6}$, nearly independent of $R_{\text {chemaq }}$. The highest value of $L_{\text {bact }}(0.4 \%)$ is observed for highest $R_{\text {bact }}\left(R_{\text {bact }}=10^{-4} \mathrm{~s}^{-1} ;\right.$ Fig. $\left.7 \mathrm{c}\right)$. This corresponds to nearly a quarter of the total loss $\left(L_{\mathrm{t}} \leq 1.4 \%\right.$; Fig. $\left.6 \mathrm{c}\right)$. To further explore why $L_{\text {bact }}$ has a maximum for these intermediate values of $K_{\mathrm{H}}$, we compare $L_{\text {bact }}$ for $K_{\mathrm{H}}=10^{2}, 10^{5}$, and $10^{9} \mathrm{M} \mathrm{atm}^{-1}$ for $R_{\text {bact }}=10^{-6} \mathrm{~s}^{-1}, R_{\text {chemgas }}=10^{-6} \mathrm{~s}^{-1}$, and $R_{\text {chemaq }}=10^{-11} \mathrm{~s}^{-1}$, i.e., for the same conditions as the ex- 
amples in Fig. 4b and d. When $K_{\mathrm{H}}$ is low $\left(10^{2} \mathrm{Matm}^{-1}\right)$, a very small fraction $(0.16 \%)$ of the organics is dissolved; thus, $L_{\text {bact }}$ is lowest. For $K_{\mathrm{H}}=10^{9} \mathrm{M} \mathrm{atm}^{-1}$ (Fig. $4 \mathrm{~b}$, blue line), $[\mathrm{Org}]_{\mathrm{aq}}$ is low because - as mentioned before - it is consumed quickly and the transport from the gas phase is not fast enough, resulting in a low $L_{\text {bact }}$. For $K_{\mathrm{H}} \sim 10^{5} \mathrm{M} \mathrm{atm}^{-1}$ (Fig. 4b, blue line), $[\mathrm{Org}]_{\mathrm{aq}}$ is relatively high, because the thermodynamic equilibrium can be more quickly established and thus $L_{\text {bact }}$ is high.

For each set of conditions, i.e., in the various panels of Fig. 7, the maximum value $L_{\text {bact }}$ is independent of $R_{\text {chemaq }}$ and does not greatly vary for the same $R_{\text {bact }}\left(L_{\text {bact,max }} \sim\right.$ $0.05 \%$ ) (Fig. 7b, d, e). This is unlike the trends of $\mathrm{fr}_{\text {bact }}$ (Fig. 2) that show a decrease with increasing $R_{\text {chemaq. }}$ By definition (Eq. 7), $\mathrm{fr}_{\text {bact }}$ and $\mathrm{fr}_{\text {chemaq }}$ are coupled; thus, an increase in one value causes a decrease in the other. Contrary, $L_{\text {bact }}$ is independent of the chemical contributions as it describes the absolute consumption rate related to the initial organic concentration. Comparing the trends in Figs. 2 and 7, it is evident that the maximum of $L_{\text {bact }}$ (intermediate $K_{\mathrm{H}}$, independent of $R_{\text {chemaq }}$ ) does not coincide with the parameter ranges for which $\mathrm{fr}_{\text {bact }}$ is maximum (highest $K_{\mathrm{H}}$, lowest $\left.R_{\text {chemaq }}\right)$. This finding highlights that previous estimates on the importance of biodegradation that were solely based on comparing rates (e.g., Jaber et al., 2020) are misleading. In these studies, it was concluded that biodegradation for highly soluble compounds is likely most important.

\subsection{3 $L_{\mathrm{t}}$ and $L_{\text {bact }}$ for CCN-derived compounds}

For CCN-derived compounds, the analysis of trends in $L_{\mathrm{t}}$ is simpler as it is the sum of $L_{\text {bact }}$ and $L_{\text {chemaq }}$ only. $L_{\mathrm{t}}$ increases with increasing $R_{\text {chemaq }}$, nearly independently of $R_{\text {bact }}$ up to a maximum value of $\sim 1.1 \%$ (Fig. $8 \mathrm{a}$ ). Comparison of $L_{\mathrm{t}}$ to $L_{\text {bact }}$ (Fig. 8b) shows that the consumption by bacteria is smaller by several orders of magnitude $\left(L_{\text {bact, } \max }=0.005 \%\right)$; thus, it is not a major contribution to the total loss. Figures 3 and $8 \mathrm{~b}$ exhibit similar contours; i.e., after $600 \mathrm{~s}$ simulation time, the highest relative and absolute contributions are predicted for CCN-derived compounds with intermediate bacterial and low aqueous-phase chemical activity. The trend in Fig. 8b can also be explained by the findings in Fig. 4: after $600 \mathrm{~s}$, the $\mathrm{CCN}$-derived compounds in the bacteria-containing droplets are completely depleted for high $R_{\text {bact }}$; thus, both fr fract $_{\text {and }} L_{\text {bact }}$ approach zero. Since there is no exchange with the gas phase or other replenishment of $\mathrm{CCN}$-derived compounds into bacteria-containing

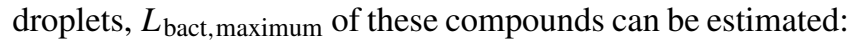
if one assumes in a first approximation that the mass fraction of $\mathrm{CCN}$-derived compounds in the initial $\mathrm{CCN}$ population scales with the liquid water content associated with the resulting droplets, one can conclude that at most $0.0065 \%$ (= LWC(bacteria-containing droplets / total LWC) can be consumed.

\subsection{Comparison of our model approach to simplified assumptions}

\subsubsection{Simplified model approaches}

The results in Fig. 4 demonstrate that the coupled equilibria between the gas phase and the droplets with and without bacteria need to be considered, in order to correctly predict the organic sink strength by bacterial processes in the multiphase system. Previous estimates of the role of biodegradation in the multiphase system have been performed assuming simplified assumptions. (i) For the bulk model, biodegradation and chemical rates were compared in a bulk aqueous phase (Vaitilingom et al., 2013) or in a population of droplets with identical composition (Jaber et al., 2020). However, since the bacterial cell concentration $\left(\sim 0.01\right.$ cells cm$\left.~^{-3}\right)$ in clouds is much smaller than the droplet number concentration $\left(=263\right.$ droplets $\mathrm{cm}^{-3}$, in our model), this results in a ratio of $\sim 4 \times 10^{-5}$ bacterial cells per droplet. (ii) For the lowLWC model, the multiphase system is considered with only droplets that contain an intact bacterial cell, resulting in a liquid water content of $\sim 10^{-11} \mathrm{vol} / \mathrm{vol}$, similar to Fankhauser et al. (2019). In Fig. 9, we schematically contrast these approaches. While it is clear that none of the two approaches reflect the conditions as encountered in real clouds, we will analyze in the following the extent to which these simplified model approaches lead to similar results as predicted in our detailed model discussed so far (Fig. 1).

\subsubsection{Comparison of $\mathrm{fr}_{\text {bact }}, L_{\mathrm{t}}$, and $L_{\text {bact }}$ using simplified model approaches}

For water-soluble organic gases, we compare $\mathrm{fr}_{\text {bact }}$ and $L_{\text {bact }}$ for the three model approaches for the full range of $K_{\mathrm{H}}$ values, $R_{\text {bact }}=10^{-6} \mathrm{~s}^{-1}, R_{\text {chemaq }}=10^{-7} \mathrm{~s}^{-1}$, and $R_{\text {chemgas }}=$ $10^{-6} \mathrm{~s}^{-1}$ (Fig. 9a, b). For $10^{2} \leq K_{\mathrm{H}}\left[\mathrm{M} \mathrm{atm}^{-1}\right] \leq 10^{4}$, only a small difference in fr bact and $L_{\text {bact }}$ is predicted for a given $R_{\text {bact }}$ because of the low organic fraction in the aqueous phase. For all $K_{\mathrm{H}}$ values, fr bact is the highest for the lowLWC model approach, because it only considers bacteriacontaining droplets and thus neglects the aqueous-phase chemistry in a majority of droplets; therefore, $\mathrm{fr}_{\text {chemaq }}$ is significantly underestimated. Consequently, the competition between biodegradation and chemical degradation takes place only in the bacteria-containing droplets, and $\mathrm{fr}_{\text {bact }}$ is the highest.

For $10^{5} \leq K_{\mathrm{H}}\left[\mathrm{M} \mathrm{atm}^{-1}\right] \leq 10^{7}, L_{\text {bact }}$ values based on the bulk and low-LWC models are higher than for the detailed model. For example, for $K_{\mathrm{H}}=10^{6} \mathrm{M} \mathrm{atm}^{-1}, L_{\text {bact }}$ values in the low-LWC model are 4.3 and 12.7 times higher than in the bulk and our detailed models, respectively. For the highest $K_{\mathrm{H}}\left(10^{7} \leq K_{\mathrm{H}}\left[\mathrm{M} \mathrm{atm}^{-1}\right] \leq 10^{9}\right)$, the comparison of $L_{\text {bact }}$ for $R_{\text {bact }}=10^{-6} \mathrm{~s}^{-1}$ shows that both simplified model approaches overestimate $L_{\text {bact }}$ by up to several orders of magnitude (Fig. 9b) for $K_{\mathrm{H}}=10^{8} \mathrm{M} \mathrm{atm}^{-1}\left(L_{\text {bact,lowLWC }}=5.8 \times\right.$ 

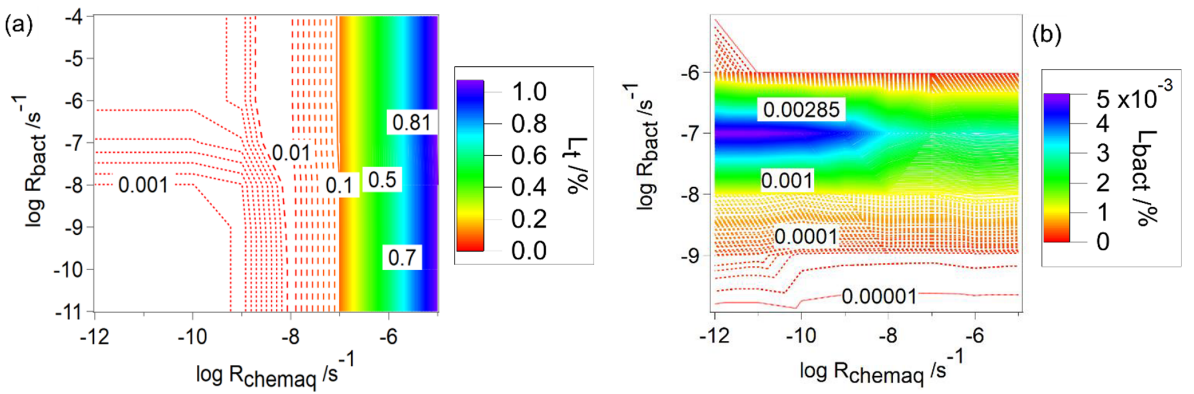

Figure 8. Predicted loss of CCN-derived species as a function of $R_{\text {chemaq }}$ and $R_{\text {bact }},(\mathbf{a})$ total loss $\left(L_{\mathrm{t}}\right),(\mathbf{b})$ loss by biodegradation $\left(L_{\mathrm{bact}}\right)$.

(a)

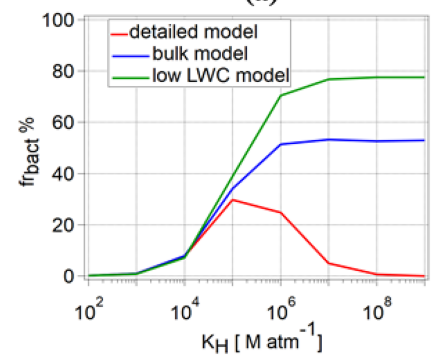

(c)

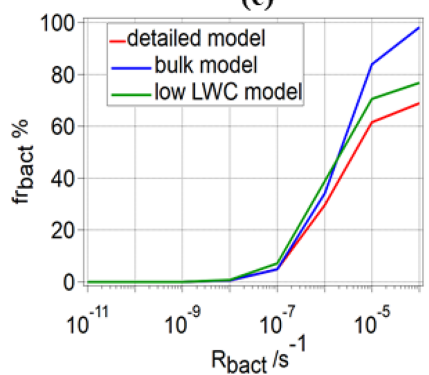

(b)

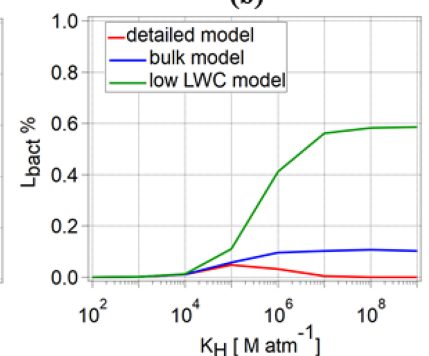

(d)

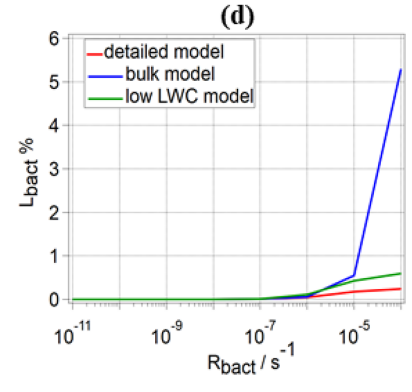

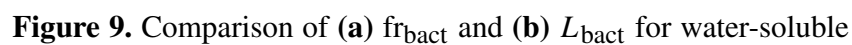
organic gases for three different model approaches: detailed model (red line), bulk approach (blue line), and low-LWC model (green line) for different values of $K_{\mathrm{H}}, R_{\text {chemaq }}=10^{-7} \mathrm{~s}^{-1}, R_{\text {bact. }}=$ $10^{-6} \mathrm{~s}^{-1}$, and $R_{\text {chemgas }}=10^{-6} \mathrm{~s}^{-1}$; (c) fr bact and (d) $L_{\text {bact }}$ for water-soluble organic gases for the same approaches for different $R_{\text {bact }}$, one value for $K_{\mathrm{H}}=10^{5} \mathrm{M} \mathrm{atm}^{-1}$, two values for $R_{\text {chemaq }}$ $\left(10^{-7} \mathrm{~s}^{-1}, 10^{-11} \mathrm{~s}^{-1}\right)$, and $R_{\text {chemgas }}=10^{-6} \mathrm{~s}^{-1}$.

$10^{-1} \% ; \quad L_{\text {bact,bulk }}=1.07 \times 10^{-1} \% ; \quad L_{\text {bact,detailed }}=6.12 \times$ $10^{-4} \%$ ). For organics with intermediate or low solubility, the differences between the three models are smaller. Given that we identified biodegradation to be most important for organics with intermediate solubility (Sect. 3.2.2), we compare fr $_{\text {bact }}$ and $L_{\text {bact }}$ for $K_{\mathrm{H}}=10^{5} \mathrm{M} \mathrm{atm}^{-1}, R_{\text {chemgas }}=10^{-6} \mathrm{~s}^{-1}$, and $R_{\text {chemaq }}=10^{-7} \mathrm{~s}^{-1}$ as a function of $R_{\text {bact }}$ (Fig. $9 \mathrm{c}, \mathrm{d}$ ). Similar to the results from the detailed model (Sect. 3.1.2), the low-LWC approach leads to $\mathrm{fr}_{\text {bact }}<100 \%$ at $t=600 \mathrm{~s}$, because organics are efficiently consumed in the bacteriacontaining droplets. However, for the bulk model, $\mathrm{fr}_{\text {bact }}$ is $\sim 100 \%$ for the highest $R_{\text {bact }}$, even after 600 s, because bac-

terial processes take place in all droplets with a reduced efficiency as compared to the processes in the single droplet in the detailed model. Consequently, the concentration of organics in all droplets remains relatively high for extended timescales, even for the highest $R_{\text {bact }}$. Figure 9d shows the dependence of $L_{\text {bact }}$ between the three models on $R_{\text {bact }}$ : for $R_{\text {bact }} \leq 10^{-6} \mathrm{~s}^{-1}, L_{\text {bact }}$ is similar for the detailed and the bulk models $\left(\sim 5 \times 10^{-4} \%\right)$, whereas it is twice as high for the low-LWC model $\left(\sim 1 \times 10^{-3} \%\right)$. However, for the highest $R_{\text {bact }}\left(10^{-4} \mathrm{~s}^{-1}\right)$, the highest $L_{\text {bact }}$ is predicted by the bulk approach $(\sim 5 \%)$ which is more than 2 orders of magnitude higher than predicted from the detailed model $(\sim 0.2 \%)$. The similarity of $L_{\text {bact }}$ between the detailed and the bulk models for $R_{\text {bact }}=10^{-6} \mathrm{~s}^{-1}$ is due to the efficient replenishment of organics with intermediate $K_{\mathrm{H}}$ (Fig. 5); i.e., the amounts of organics available to bacteria are similar. However, for the highest $R_{\text {bact }}, L_{\text {bact }}$ is much higher for the bulk model, because the consumption of the organics occurs without any kinetic limitations of the various transport processes that are only presented by the detailed model.

For the CCN-derived compounds, we compare fr bact $_{\text {bet }}$ and $L_{\text {bact }}$ for different $R_{\text {bact }}$ and two $R_{\text {chemaq }}\left(10^{-11}\right.$ and $10^{-7} \mathrm{~s}^{-1}$ ) (Fig. S4a, b). For $R_{\text {bact }}=10^{-8} \mathrm{~s}^{-1}$ and $R_{\text {chemaq }}=$ $10^{-11} \mathrm{~s}^{-1}$, fr bact is about $99 \%$ for all three approaches, which is not the case for highest $R_{\text {chemaq }}\left(10^{-7} \mathrm{~s}^{-1}\right)$ (Fig. S4a). However, for $R_{\text {bact }}=10^{-4} \mathrm{~s}^{-1}, \mathrm{fr}_{\text {bact }}$ is $\sim 0 \%$ (at $t=600 \mathrm{~s}$ ) in the detailed model for both $R_{\text {chemaq }}$ values for the reasons explained in Sect. 3.1.2, whereas $\mathrm{fr}_{\text {bact }} \sim 99 \%$ for the bulk model because of continuous bacterial activity in all droplets. Moreover, $\mathrm{fr}_{\text {bact }}$ and $L_{\text {bact }}$ are always $100 \%$ for the low-LWC model. The role of aqueous-phase chemistry in the multiphase system is predicted to be negligible by the low-LWC approach as it is equally reduced as the LWC, leading to the dominance of the bacterial processes. If we compare $L_{\text {bact }}$ for the bulk (blue line in Fig. S4b) and the detailed models (red line), one finds an increasing discrepancy between the model results: for the lowest $R_{\text {bact }}$ considered here $\left(10^{-8} \mathrm{~s}^{-1}\right)$ and the two $R_{\text {chemaq values }: 10^{-11} \mathrm{~s}^{-1}}$ and $10^{-7} \mathrm{~s}^{-1}$, respectively, $L_{\text {bact }}$ for the bulk model is predicted to be $\sim 9.3$ and 11.6 times higher than for the detailed model. For $R_{\text {bact }}=10^{-6} \mathrm{~s}^{-1}$ and the two $R_{\text {chemaq }}$ val- 
ues, this factor increases to $2.5 \times 10^{4}$ and $1.3 \times 10^{6}$. For the highest $R_{\text {bact }}=10^{-4} \mathrm{~s}^{-1}, L_{\text {bact }}$ between the bulk and our detailed model after $600 \mathrm{~s}$ of simulation cannot be reasonably compared as in the detailed model after $<100 \mathrm{~s}$. The CCNderived compounds in the bacteria-containing droplets are completely depleted for high $R_{\text {bact }}$; thus, no further consumption occurs ( $\left.L_{\text {bact }} \sim 0 \%\right)$ (Sect. 3.2.3). In the bulk model, the organic consumption by bacteria is predicted to occur continuously as the bacteria could, in theory, consume all organics on "infinite" timescales.

Our model comparison shows that for water-soluble organic gases and $\mathrm{CCN}$-derived compounds, both the bulk and low-LWC models overestimate the importance of biodegradation, i.e., both $\mathrm{fr}_{\text {bact }}$ and $L_{\text {bact }}$. The biases are highest in the bulk approach for high $R_{\text {bact }}$ and high $K_{\mathrm{H}}$. Also, the comparison shows that the bulk approach leads to wrong conclusions in terms of the importance of biodegradation as a function of the solubility of organics. Our model analysis emphasizes that a detailed model is needed in order to correctly represent the partitioning of water-soluble organic gases between the gas phase and the droplets with and without bacteria.

\section{Atmospheric implications: how important is biodegradation for organic compounds identified in cloud water?}

\section{1 $L_{\text {bact }}$ of organic cloud water constituents}

Based on our model sensitivity studies discussed in the previous sections and the literature data for cloud water organics summarized in Tables 1 and 2, we assess the importance of biodegradation of these compounds. The contour plots representations in Fig. 10 are the same as in Fig. 7ac (water-soluble organic gases) and Fig. $8 \mathrm{~b}$ (CCN-derived compounds). The added symbols correspond to $L_{\text {bact }}$ of the compounds in Table 1 for a single $R_{\text {bact }}$ in each figure panel. Given that $R_{\text {chemgas }}$ only differs by about 2 orders of magnitude for the organics in Table 1, we present the results with $R_{\text {chemgas }}=10^{-6} \mathrm{~s}^{-1}$. The reasoning for the assumed single $R_{\text {bact }}$ is further discussed in Sect. 4.2.

For the carboxylic acids, two values are shown, i.e., $K_{\mathrm{H}(\mathrm{eff})}$ and $R_{\text {chemaq }}$ at $\mathrm{pH}=3$ and 6 (Table 3). $R_{\text {chemaq }}$ at the two $\mathrm{pH}$ values are calculated based on the rate constants $k_{\text {chemaq }}$ as a function of the proportion of the acidic and anionic forms depending on $\mathrm{pH}$ and $\mathrm{pK}_{\mathrm{a}}$ and the rate constants of the $\mathrm{OH}$ reactions for the acid and anion. Similarly, rate constants for other (e.g., $\mathrm{NO}_{3}$ ) reactions could be derived using data summarized in Table 1.

As discussed in Sect. 2.2.2 and by Vaïtilingom et al. (2013), the bacterial activity does not show any systematic difference in this $\mathrm{pH}$ range; therefore, we only show one $R_{\text {bact }}$ value for each acid. For the lowest $R_{\text {bact }}\left(10^{-8} \mathrm{~s}^{-1}\right)$, the physicochemical properties ( $\left.K_{\mathrm{H} \text { (eff) }}, R_{\text {chemaq }}\right)$ of the water-soluble organic gases (acetic acid / acetate, formic acid / formate, formaldehyde, catechol, phenol and methanol) are in the range where $L_{\text {bact }}$ has its minimum values of $\sim 10^{-6} \leq L_{\text {bact }}[\%] \leq 10^{-3}$ (Fig. 10a).

For higher $R_{\text {bact }}\left(10^{-6} \mathrm{~s}^{-1}\right.$, Fig. $\left.10 \mathrm{~b}\right)$, which implies higher cell concentration in the cloud, highly soluble compounds, such as acetate and catechol, are in the range where $L_{\text {bact }}$ shows a maximum $\left(\sim 0.04 \leq L_{\text {bact }}[\%] \leq 0.06\right)$ and less soluble compounds such as formic acid, formate, and formaldehyde $\left(10^{4}<K_{\mathrm{H}(\mathrm{eff})}\left[\mathrm{M} \mathrm{atm}^{-1}\right]<10^{6}\right)$ are in the area where $\sim 0.02 \leq L_{\text {bact }}[\%] \leq 0.04$. Less soluble compounds $\left(K_{\mathrm{H}(\mathrm{eff})}<10^{3} \mathrm{M} \mathrm{atm}^{-1}\right)$, such as acetic acid, phenol, and methanol are in the area of much lower $L_{\text {bact }}\left(\sim 10^{-5} \leq\right.$ $\left.L_{\text {bact }}[\%] \leq 10^{-3}\right)$. As discussed in Sect. 3.2, the maximum value of $L_{\text {bact }}$ increases with higher $R_{\text {bact }}$ and is predicted for compounds with moderate $K_{\mathrm{H}(\text { eff) }}$ (Fig. 5). Therefore, at the highest assumed $R_{\text {bact }}\left(10^{-4} \mathrm{~s}^{-1}\right)$, the less soluble compounds formic acid, formaldehyde, and acetic acid are in the range where $L_{\text {bact }}$ has its maximum values $\left(0.3<L_{\text {bact }}[\%]\right.$ $<0.4$; Fig. 10c).

Figure $10 \mathrm{~d}$ repeats the full parameter ranges of $R_{\text {bact }}$ and $R_{\text {chemaq. }}$. We discuss $L_{\text {bact }}$ for the CCN-derived compounds (malonic acid, malonate, succinic acid, succinate) for the same $R_{\text {bact }}$ as in Fig. 10a-c: the maximum consumption of $\mathrm{CCN}$-derived compounds by bacteria corresponds to the fraction of the organics present in bacteria-containing droplets ( $\sim 0.0065 \%$ in our simulations). Therefore, the predicted $L_{\text {bact }}[\%]$ values are very similar for all compounds considered here (malonate / malonic acid and succinate / succinic acid) and do not differ, independently of $R_{\text {bact }}$.

\subsection{Dependence of $L_{\text {bact }}$ on bacterial cell concentration in cloud water}

According to Eq. (3), $R_{\text {bact }}$ is the product of the biodegradation rate constant $k_{\text {bact }}$ [cell $\mathrm{L}^{-1}$ ] (Table 2) and the cell concentration $C_{\text {cell }}$ [cell $\mathrm{L}^{-1}$ ]. Based on the three $R_{\text {bact }}$ values and the $k_{\text {bact }}$ data for the various organics, we calculate $C_{\text {cell, theoretical }}$ that would be needed to reach these $R_{\text {bact }}$ :

$C_{\text {cell, theoretical }}\left[\right.$ cell $\left.\mathrm{L}^{-1}\right]=\frac{R_{\text {bact }}\left[\mathrm{s}^{-1}\right]}{k_{\text {bact }}\left[\mathrm{Lcell}^{-1} \mathrm{~s}^{-1}\right]}$.

The resulting $C_{\text {cell, theoretical }}$ [cell $\mathrm{L}^{-1}$ ] values are listed in Table 3 , together with $k_{\text {bact }}$ [cell $\mathrm{L}^{-1}$ ]. Among the water-soluble organic gases, $C_{\text {cell, theoretical }}$ is predicted to be $\sim 10^{2} \leq$ $C_{\text {cell,theoretical }}\left[\right.$ cell $\mathrm{L}^{-1}$ ] $\leq 10^{7}$ for acetic acid, formic acid, and phenol, while it is much higher $\left(\sim 10^{7} \leq C_{\text {cell, theoretical }}\right.$ $\left[\right.$ cell $\left.\mathrm{L}^{-1}\right] \leq 10^{15}$ ) for catechol, formaldehyde, and methanol that have much lower $k_{\text {bact }}$ than the former compounds. Typical bacterial cell concentrations in cloud water are in the range of $10^{6}-10^{8}$ cell $\mathrm{L}^{-1}$ (Amato et al., 2007b). Comparing this range to $C_{\text {cell, theoretical reveals that for several com- }}$ pounds $C_{\text {cell, theoretical falls into a realistic range (values with }}$ * in Table 3); for ambient cell concentrations in cloud water, malonic acid / malonate, succinic acid / succinate, acetic acid / acetate, formic acid/formate, cathecol, and phenol 

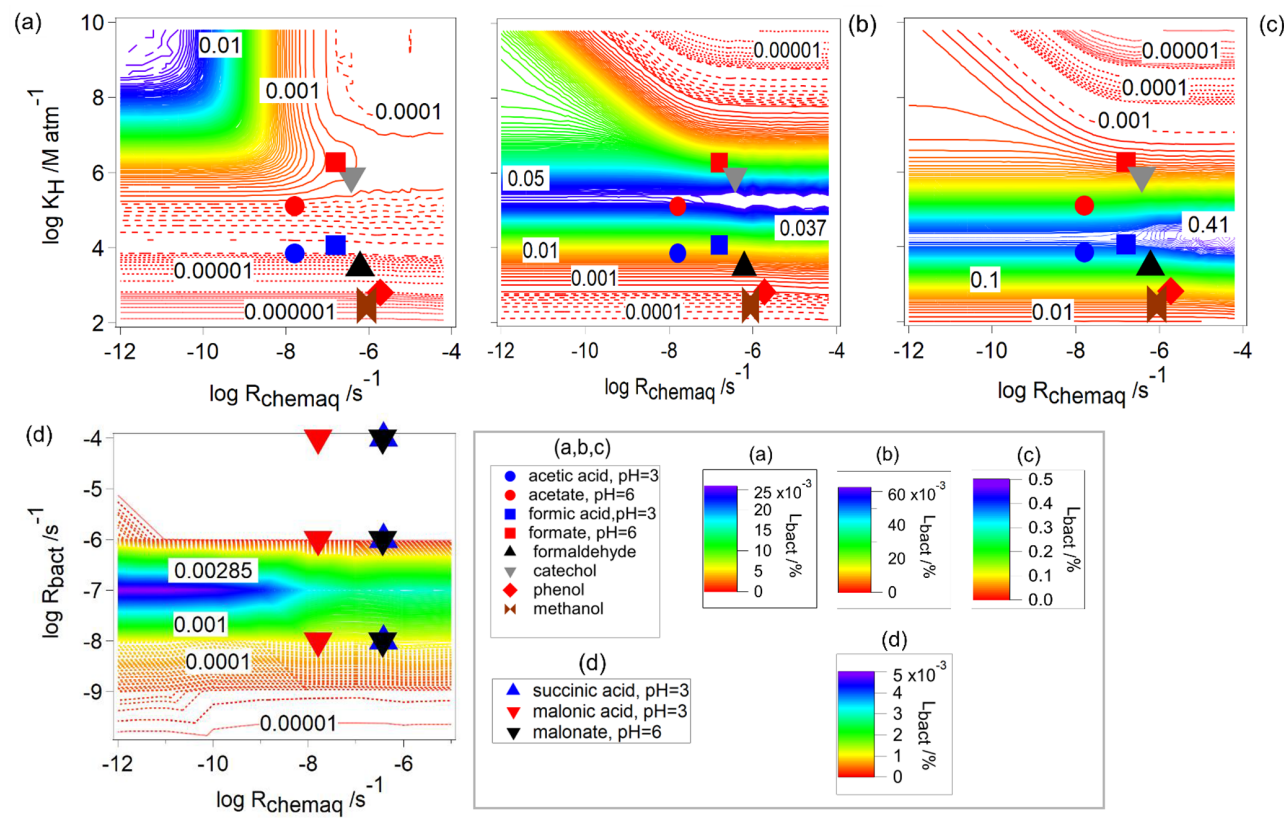

Figure 10. (a-c) $L_{\text {bact }}$ for water-soluble organic gases. The contour plots are identical to Fig. 7a-c. Symbols show combinations of $R_{\text {chemaq }}$ and $K_{\mathrm{H}}$ for specific compounds (Table 1). For all simulations, $R_{\text {chemgas }}=10^{-6} \mathrm{~s}^{-1}$; (a) $R_{\text {bact }}=10^{-8} \mathrm{~s}^{-1}$, (b) $R_{\text {bact }}=10^{-6} \mathrm{~s}^{-1}$, (c) $R_{\text {bact }}=10^{-4} \mathrm{~s}^{-1}$, and (d) $L_{\text {bact }}$ for CCN-derived organics (Table 1). The contour plot is identical to Fig. $8 \mathrm{~b}$. Note that $R_{\text {chemaq }}$ and $R_{\text {bact }}$ for succinate $(\mathrm{pH}=6)$ are nearly identical to the values for succinic acid $(\mathrm{pH}=3)$ and were therefore omitted from the figure.

might fall into a range where the maximum consumption of organics by biodegradation can be expected, while for formaldehyde and methanol $C_{\text {cell, theoretical }}$ is unrealistic ( $\geq$ $10^{9}$ cells $\mathrm{L}^{-1}$ ) based on the available studies of bacterial cell concentrations in cloud water.

\subsection{For which organics is biodegradation an efficient sink in the atmosphere?}

The maximum value of $L_{\text {bact }}$ is $\sim 0.7 \%$ in all our simulations, but one should keep in mind that also the predicted $L_{\mathrm{t}}$ is not higher than a few percent (Fig. 6a-c) as we restrict our simulations to the timescale of approximate one cloud cycle. However, in a relative sense, our results allow us to compare the importance of biodegradation to chemical loss for the compounds shown in Fig. 10. To quantify the contribution of bacteria to the total consumption $\left(L_{\mathrm{t}}\right)$, we list the ratio $L_{\text {bact }} / L_{\mathrm{t}}$ in Table 3. Our results clearly show that biodegradation might add significantly to the loss of formic acid / formate $\left(L_{\text {bact }} / L_{\mathrm{t}}=0.65\right)$ and acetic acid / acetate $\left(L_{\text {bact }} / L_{\mathrm{t}}=0.70\right)$ at cell concentrations of $\sim 7 \times 10^{7}$ and $2 \times 10^{6}$ cells $\mathrm{L}^{-1}$, respectively. These acids contribute on average $\sim 68 \%$ to the total dissolved carbon in cloud and fog water (Herckes et al., 2013). Their removal by dry and wet deposition is considered the major loss process in the atmosphere (Khare et al., 1999). However, several studies also suggested that the oxidation of formic acid / formate in cloud water may be a net sink (Jacob, 1986). Measurements during different seasons in the
Amazon showed that indeed formic and acetic acids have stronger sinks during the wet season (Herlihy et al., 1987). While wet deposition was described to contribute, to a large extent, to the observed removal; chemical and possibly bacterial processes were suggested to act as additional sinks. While the latter was regarded as being inefficient due to long incubation time as observed in lab experiments, more recent experiments suggest that such incubation times are likely not occurring in the atmosphere where bacterial cells are continuously exposed to water and substrates (Amato et al., 2007a; Vaitilingom et al., 2010, 2013). We conclude that biodegradation of these major cloud water organics may be a significant sink under ambient conditions, possibly even comparable to the loss by chemical reactions. While phenol is not a major contributor to the WSOC content in cloud water (5$95 \mathrm{nM}$ ) (Jaber et al., 2020) as compared to $10 \mu \mathrm{M}$ (Ervens et al., 2003b; Löflund et al., 2002; Sun et al., 2016) for formic and acetic acids, respectively, its degradation processes in the atmosphere might be of interest due to its toxic properties. Overall, our results are in agreement with previous findings that neither chemical processes nor biodegradation are major WSOC losses as compared to deposition (Ervens and Amato, 2020; Fankhauser et al., 2019). However, in order to comprehensively describe the loss processes and timescales of organic degradation and residence timescales in the atmosphere, both chemical and biological processes should be considered. Hence, we suggest that biological processes of organics with properties similar to those of formic and 
Table 3. $k_{\text {bact }}$ [cell L ${ }^{-1}$ ] calculated from literature data, theoretical $C_{\text {cell }}$ [cell L ${ }^{-1}$ ] based on Eq. (14), and the ratio $L_{\text {bact }} / L_{\mathrm{t}}$ for three $R_{\text {bact }}$ values $\left(10^{-8}, 10^{-6}\right.$ and $\left.10^{-4} \mathrm{~s}^{-1}\right)$ for water-soluble organic gases and $\mathrm{CCN}$-derived compounds. Values with ${ }^{*}$ show bacterial concentrations that are realistic for cloud water.

\begin{tabular}{|c|c|c|c|c|c|c|c|}
\hline \multirow[t]{3}{*}{ Organic compound } & \multirow[t]{3}{*}{$\begin{array}{r}k_{\text {bact }} \\
{\left[\text { L cell }^{-1} \mathrm{~s}^{-1}\right]}\end{array}$} & \multicolumn{3}{|c|}{$\begin{array}{c}C_{\text {cell, theoretical }}\left[\text { cell } \mathrm{L}^{-1} \text { ] }\right. \\
\text { based on Eq. }(14)\end{array}$} & \multicolumn{3}{|c|}{$\begin{array}{l}L_{\text {bact, } \max } \\
{[\%]}\end{array}$} \\
\hline & & \multicolumn{3}{|c|}{$R_{\text {bact }}$} & \multicolumn{3}{|c|}{$R_{\text {bact }}$} \\
\hline & & $10^{-8} \mathrm{~s}^{-1}$ & $10^{-6} \mathrm{~s}^{-1}$ & $10^{-4} \mathrm{~s}^{-1}$ & $10^{-8} \mathrm{~s}^{-1}$ & $10^{-6} \mathrm{~s}^{-1}$ & $10^{-4} \mathrm{~s}^{-1}$ \\
\hline \multicolumn{8}{|l|}{ CCN-derived compounds } \\
\hline Malonic acid & \multirow{2}{*}{$9.0 \times 10^{-13}$} & \multirow{2}{*}{$3.3 \times 10^{4}$} & \multirow{2}{*}{$3.3 \times 10^{6^{*}}$} & \multirow{2}{*}{$1.1 \times 10^{8^{*}}$} & \multicolumn{3}{|c|}{$\leq 0.0065 \%$} \\
\hline Malonate & & & & & \multicolumn{3}{|c|}{$\left(=\mathrm{LWC}_{\text {bact }} / \mathrm{LWC}_{\text {total }}\right)$} \\
\hline Succinic acid, Succinate & $3.0 \times 10^{-13}$ & $3.3 \times 10^{4}$ & $3.3 \times 10^{6^{*}}$ & $3.3 \times 10^{8^{*}}$ & & & \\
\hline \multicolumn{8}{|c|}{ Water-soluble organic gases } \\
\hline & & & & & $L_{\text {bact }} / L_{\mathrm{t}}$ & $L_{\text {bact }} / L_{\mathrm{t}}$ & $L_{\text {bact }} / L_{\mathrm{t}}$ \\
\hline Acetic acid & \multirow{2}{*}{$4.7 \times 10^{-11}$} & $2.1 \times 10^{2}$ & $2.1 \times 10^{4}$ & \multirow{2}{*}{$2.1 \times 10^{6^{*}}$} & $5.8 \times 10^{-4}$ & $5.8 \times 10^{-2}$ & $7.0 \times 10^{-1^{*}}$ \\
\hline Acetate & & $7.1 \times 10^{3}$ & $7.1 \times 10^{5}$ & & $8.0 \times 10^{-2}$ & $3.3 \times 10^{-1}$ & $6.7 \times 10^{-1^{*}}$ \\
\hline Formic acid & \multirow{2}{*}{$1.4 \times 10^{-12}$} & $7.1 \times 10^{3}$ & $7.1 \times 10^{5}$ & \multirow{2}{*}{$7.1 \times 10^{7^{*}}$} & $6.2 \times 10^{-4}$ & $7.4 \times 10^{-2}$ & $6.5 \times 10^{-1^{*}}$ \\
\hline Formate & & $1.4 \times 10^{9}$ & $1.4 \times 10^{11}$ & & $1.2 \times 10^{-3}$ & $2.6 \times 10^{-2}$ & $3.4 \times 10^{-2^{*}}$ \\
\hline Formaldehyde & $7.0 \times 10^{-18}$ & $3.6 \times 10^{6}$ & $3.6 \times 10^{8}$ & $1.4 \times 10^{13}$ & $8.4 \times 10^{-4}$ & $7.4 \times 10^{-2}$ & $6.5 \times 10^{-1}$ \\
\hline Catechol & $2.7 \times 10^{-15}$ & $3.0 \times 10^{2}$ & $3.0 \times 10^{4^{*}}$ & $3.6 \times 10^{10}$ & $3.5 \times 10^{-3}$ & $1.2 \times 10^{-1}$ & $2.0 \times 10^{-1}$ \\
\hline Phenol & $3.3 \times 10^{-11}$ & $1.2 \times 10^{11}$ & $1.2 \times 10^{13}$ & $3.0 \times 10^{6^{*}}$ & $5.4 \times 10^{-5}$ & $5.4 \times 10^{-3^{*}}$ & $3.2 \times 10^{-1^{*}}$ \\
\hline Methanol & $8.1 \times 10^{-20}$ & $1.2 \times 10^{11}$ & $1.2 \times 10^{13}$ & $1.2 \times 10^{15}$ & $2.3 \times 10^{-5}$ & $2.3 \times 10^{-3}$ & $2.4 \times 10^{-1}$ \\
\hline
\end{tabular}

acetic acids and phenol $\left(\sim 10^{3}<K_{\mathrm{H}(\mathrm{eff})}\left[\mathrm{M} \mathrm{atm}^{-1}\right]<\sim 10^{6}\right.$, $k_{\text {bact }}=10^{-11} \mathrm{~s}^{-1}$ ) should be included in atmospheric multiphase models.

The importance of biodegradation of $\mathrm{CCN}$-derived compounds is limited by the number fraction of cloud droplets that contain bacteria. Malonate/malonic acid and succinate / succinic acid contribute on average to $<5 \%$ to the total organic aerosol mass in ambient particles, e.g., Fu et al. (2013) and Kawamura and Ikushima (1993). Their loss by chemical and biological processes will not affect the total carbon budget to a large extent nor the budget of the individual compounds. These conclusions can be generalized for other $\mathrm{CCN}$-derived aerosol constituents, for which biodegradation has been suggested to occur in the atmosphere. Our assumption of static cloud droplets in the box model is certainly a simplified representation of cloud microphysics. Droplets might experience collision / coalescence in clouds, leading to mixing of the cloud water constituents in the resulting larger droplets. However, such processes are unlikely to add significantly to the loss of $\mathrm{CCN}$-derived compounds by bacteria due to (i) the number small fraction of bacteria-containing droplets (0.001-0.0001) and (ii) the limited atmospheric residence time of large droplets which are efficiently removed by precipitation as a function of drop size (Beard and Ochs, 1984).

\section{Summary and conclusions}

Our model sensitivity study is the first comprehensive analysis of the importance of biodegradation of organics by bacteria in the atmospheric multiphase system in comparison to chemical loss for wide ranges of chemical and biodegradation kinetic data. We use a box model with drop-sizeresolved aqueous-phase chemistry and additional biological processes that only occur in a small number of cloud droplets, in agreement with ambient ratios of cell and droplet concentrations. We neglect the fact that bacterial cells may form agglomerates in the atmosphere; consequently, there might be more than one cell per droplet. This effect could be included in our model by multiplying the biological activity in the respective droplets with the number of cells.

We compare the predicted loss rates of chemical processes in both phases to those of biological processes in the aqueous phase only. In addition to presenting the relative loss rates $\left(\mathrm{fr}_{\text {bact }}, \mathrm{fr}_{\text {chem }}\right)$ as in previous studies (Jaber et al., 2020; 
Vaitilingom et al., 2010), we discuss the relative amounts of organics $\left(L_{\mathrm{t}}\right)$ consumed by chemical $\left(L_{\mathrm{chem}}\right)$ and biological processes $\left(L_{\text {bact }}\right)$. We find that the relative loss rate of organics by biological processes $\left(\mathrm{fr}_{\text {bact }}\right.$ ) is generally higher for water-soluble organic gases than for $\mathrm{CCN}$-derived compounds. However, the total loss of the organics $\left(L_{\mathrm{t}}\right)$ is predicted to not reach any value higher than $\sim 12 \%$, because our simulations were restricted to a period of $600 \mathrm{~s}$ (approximately the drop lifetime within one cloud cycle); it would be higher if the total particle processing time during multiple cloud cycles in the atmosphere were considered. The contribution of bacteria $\left(L_{\text {bact }}\right)$ to the total loss is predicted to be highest for water-soluble organic gases with intermediate solubility $\left(\sim 10^{4} \leq K_{\mathrm{H}}\left[\mathrm{M} \mathrm{atm}^{-1}\right] \leq \sim 10^{6}\right)$. This can be explained by the replenishment of these compounds in the bacteria-containing droplets upon uptake from the gas phase and evaporation from the bacteria-free droplets, in which less efficient consumption of the organics occurs. Less soluble organics $\left(K_{\mathrm{H}}<10^{4} \mathrm{Matm}^{-1}\right)$ that partition to a smaller extent $(<1 \%)$ to the aqueous phase are mostly consumed by chemical processes in the gas phase; more soluble compounds $\left(K_{\mathrm{H}}>10^{6} \mathrm{M} \mathrm{atm}^{-1}\right)$ are predominately partitioned to the aqueous phase. Thus, the evaporation to the gas phase and consequently the redistribution from the bacteria-free to the bacteria-containing droplets is kinetically more limited and less efficient. The ratio of the consumption of water-soluble organic gases by bacteria to the total loss $\left(L_{\text {bact }} / L_{\mathrm{t}}\right)$ might be as high as 0.7 for high biological activity and cell concentrations $\left(\sim 10^{8}\right.$ cells $\left.\mathrm{L}^{-1}\right)$. These values suggest that biological processes might add significantly $(>70 \%)$ to the loss processes in the atmospheric multiphase system for organics with intermediate solubility such as formic acid / formate, acetic acid / acetate, or phenol. For CCN-derived compounds, the amount of organics consumed by bacteria is restricted to the fraction of the organic species dissolved in bacteria-containing droplets $(\sim$ $0.001 \%$ ) as no efficient replenishment from the gas phase or from the other droplets occurs. Thus, biodegradation of $\mathrm{CCN}$-derived compounds does not significantly affect their atmospheric budget. Recent experiments of airborne bacteria suggested that metabolic rates are a function of substrate availability in oligotrophic media such as cloud droplets (Krumins et al., 2014b). In the case of CCN-derived organics or those that are inefficiently replenished by uptake from the gas phase, substrate limitation might result in lower biodegradation rates. Currently, no data are available on the absolute changes in $k_{\text {bact }}$ at different levels of substrate availability and/or on the timescales during which $k_{\text {bact }}$ might adjust to such conditions. In addition, the biodegradation rates may be affected under highly acidic conditions. Some studies demonstrated that some bacteria can develop an acid resistance to survive under acidic conditions (Lu et al., 2013). However, these strategies do not necessarily imply that the bacteria maintain the same biodegradation activities at high acidity, but they allow for survival of the cells in the atmo- sphere. It can be expected that internal buffering of bacterial cells allows them to maintain their metabolic activity over wide $\mathrm{pH}$ ranges ( $\sim 3$ to 6 ) as found in cloud water. Therefore, we do not consider a potential $\mathrm{pH}$ dependency of biodegradation rates in our model studies.

In addition to our detailed model with a realistic bacterial cell distribution within a cloud droplet population, we apply simpler model approaches: (i) similar to many chemical model studies, bacterial cells are distributed equally in all droplets ("bulk approach"), resulting in cell concentrations of $10^{-5}$ cells per droplet, which is clearly an unphysical assumption for intact bacterial cells. (ii) A multiphase system with only cloud droplets which contain bacteria resulting in a liquid water content of $\sim 10^{-11} \mathrm{vol} / \mathrm{vol}$ as compared to $\sim 10^{-7} \mathrm{vol} / \mathrm{vol}$ in clouds ("low-LWC approach") is applied. Comparing $L_{\text {bact }}$ predicted from these approaches to results of our detailed model shows that all approaches agree in predicting $L_{\text {bact }}$ for organics of low solubility $\left(K_{\mathrm{H}(\mathrm{eff})}<10^{4} \mathrm{M} \mathrm{atm}^{-1}\right)$. However, for such species the importance of biodegradation is low due to their inefficient partitioning to the aqueous phase. The bulk approach increasingly overestimates $L_{\text {bact }}$ of organics with higher $K_{\mathrm{H}}$; the greatest discrepancy is predicted for highly soluble compounds $\left(K_{\mathrm{H}(\mathrm{eff})}>10^{6} \mathrm{M} \mathrm{atm}^{-1}\right)$ as the bulk approach does not take into account the kinetic limitation due to the organic species redistribution between the bacteria-free and bacteriacontaining droplets. As the bulk approach implies organics in all droplets, it does not allow for limiting the organic species consumption by biodegradation. Predictions of the relative role of biodegradation as compared to chemical processes by the low-LWC approach are biased high, because the loss due to aqueous-phase processes is only considered in an unrealistically small fraction of droplets.

The current data sets for microbial rates of organic compounds are limited to very few compounds. Our model sensitivity study shows that biodegradation by bacteria in clouds is most efficient for compounds with intermediate (effective) Henry's law constants $\left(\sim 10^{4} \mathrm{M} \mathrm{atm}^{-1}<K_{\mathrm{H} \text { (eff) }}<\right.$ $10^{6} \mathrm{M} \mathrm{atm}^{-1}$ ) as found for common cloud water constituents such as formic acid / formate and acetic acid/acetate but also for less abundant species such as phenol, largely independent of their chemical reactivity. Our framework allows us to estimate the potential importance of biodegradation of organics in comparison to chemical processes. It also gives guidance to future lab and model studies to further explore the role of biodegradation of specific organics in the multiphase system.

Data availability. All model input data are summarized in Tables S1-S3 in the Supplement.

Supplement. The supplement related to this article is available online at: https://doi.org/10.5194/acp-21-3123-2021-supplement. 
Author contributions. $\mathrm{AK}$ and $\mathrm{BE}$ designed and carried out the model studies and wrote the article. MZ, PA, and AMD contributed with fruitful discussions and gave constructive feedback on the article.

Competing interests. The authors declare that they have no conflict of interest.

Financial support. This research has been supported by the French National Research Agency (ANR) (grant no. ANR-17-MPGA0013).

Review statement. This paper was edited by Susannah Burrows and reviewed by two anonymous referees.

\section{References}

Allou, L., El Maimouni, L., and Le Calvé, S.: Henry’s law constant measurements for formaldehyde and benzaldehyde as a function of temperature and water composition, Atmos. Environ., 45, 2991-2998, https://doi.org/10.1016/j.atmosenv.2010.05.044, 2011.

Amato, P., Demeer, F., Melaouhi, A., Fontanella, S., Martin-Biesse, A.-S., Sancelme, M., Laj, P., and Delort, A.-M.: A fate for organic acids, formaldehyde and methanol in cloud water: their biotransformation by micro-organisms, Atmos. Chem. Phys., 7, 4159-4169, https://doi.org/10.5194/acp-7-4159-2007, 2007a.

Amato, P., Parazols, M., Sancelme, M., Mailhot, G., Laj, P., and Delort, A. M.: An important oceanic source of micro-organisms for cloud water at the Puy de Dôme (France), Atmos. Environ., 41, 8253-8263, https://doi.org/10.1016/j.atmosenv.2007.06.022, $2007 b$.

Amato, P., Parazols, M., Sancelme, M., Laj, P., Mailhot, G., and Delort, A. M.: Microorganisms isolated from the water phase of tropospheric clouds at the Puy de Dôme: Major groups and growth abilities at low temperatures, FEMS Microbiol. Ecol., 59, 242254, https://doi.org/10.1111/j.1574-6941.2006.00199.x, 2007c.

Amato, P., Besaury, L., Joly, M., Penaud, B., Deguillaume, L., and Delort, A. M.: Metatranscriptomic exploration of microbial functioning in clouds, Sci. Rep.-UK, 9, 1-12, https://doi.org/10.1038/s41598-019-41032-4, 2019.

Anglada, J. M.: Complex mechanism of the gas phase reaction between formic acid and hydroxyl radical. Proton coupled electron transfer versus radical hydrogen abstraction mechanisms, J. Am. Chem. Soc., 126, 9809-9820, https://doi.org/10.1021/ja0481169, 2004.

Arakaki, T., Anastasio, C., Kuroki, Y., Nakajima, H., Okada, K., Kotani, Y., Handa, D., Azechi, S., Kimura, T., Tsuhako, A., and Miyagi, Y.: A general scavenging rate constant for reaction of hydroxyl radical with organic carbon in atmospheric waters, Environ. Sci. Technol., 47, 8196-8203, https://doi.org/10.1021/es401927b, 2013.

Ariya, P. A., Nepotchatykh, O., Ignatova, O., and Amyot, M.: Microbiological degradation of atmospheric or- ganic compounds, Geophys. Res. Lett., 29, 34-41, https://doi.org/10.1029/2002gl015637, 2002.

Aumont, B., Madronich, S., Bey, I., and Tyndall, G.: Contribution of Secondary VOC to the Composition of Aqueous Atmospheric Particles: A Modeling Approach, J. Atmos. Chem., 35, 59-75, https://doi.org/10.1023/a:1006243509840, 2000.

Beard, K. V. and Ochs, H. T.: Collection and coalescence efficiencies for accretion, J. Geophys. Res., 89, 7165-7169, https://doi.org/10.1029/JD089iD05p07165, 1984.

Butkovskaya, N. I., Kukui, A., Pouvesle, N., and Le Bras, G.: Rate constant and mechanism of the reaction of $\mathrm{OH}$ radicals with acetic acid in the temperature range of 229-300 K, J. Phys. Chem. A, 108, 7021-7026, https://doi.org/10.1021/jp048444v, 2004.

Cabelli, D. E. and Bielski, B. H.: pulse radiolysis study of some dicarboxylic acids of the citric acid cycle. The kinetics and spectral properties of the free radicals formed by reactions with the HO radical, Z. Naturforsch. B, 40, 1731-1737, https://doi.org/10.1515/znb-1985-1223, 1985.

Cantrell, C. A., Shetter, R. E., Calvert, J. G., Eisele, F. L., and Tanner, D. J.: Some considerations of the origin of nighttime peroxy radicals observed in MLOPEX 2c, J. Geophys. Res.-Atmos., 102, 15899-15913, https://doi.org/10.1029/97jd01120, 1997.

Decesari, S., Facchini, M. C., Fuzzi, S., and Tagliavini, E.: Characterization of water-soluble organic compounds in atmospheric aerosol: A new approach, J. Geophys. Res.-Atmos., 105, 14811489, https://doi.org/10.1029/1999JD900950, 2000.

Deguillaume, L., Charbouillot, T., Joly, M., Vaïtilingom, M., Parazols, M., Marinoni, A., Amato, P., Delort, A.-M., Vinatier, V., Flossmann, A., Chaumerliac, N., Pichon, J. M., Houdier, S., Laj, P., Sellegri, K., Colomb, A., Brigante, M., and Mailhot, G.: Classification of clouds sampled at the puy de Dôme (France) based on $10 \mathrm{yr}$ of monitoring of their physicochemical properties, Atmos. Chem. Phys., 14, 1485-1506, https://doi.org/10.5194/acp14-1485-2014 2014.

Delort, A.-M., Vaïtilingom, M., Amato, P., Sancelme, M., Parazols, M., Mailhot, G., Laj, P., and Deguillaume, L.: A short overview of the microbial population in clouds: Potential roles in atmospheric chemistry and nucleation processes, Atmos. Res., 98, 249-260, https://doi.org/10.1016/j.atmosres.2010.07.004, 2010.

Delort, A.-M., Deguillaume, L., Renard, P., Vinatier, V., Canet, I., Vaïtilingom, M., and Chaumerliac, N.: Impacts on Cloud Chemistry, in: Microbiology of Aerosols, edited by: Delort, A. M. and Amato, P., John Wiley \& Sons, Inc., Hoboken, NJ, 221-248, https://doi.org/10.1002/9781119132318.ch3b, 2017.

Ervens, B.: Modeling the Processing of Aerosol and Trace Gases in Clouds and Fogs, Chem. Rev., 115, 4157-4198, https://doi.org/10.1021/cr5005887, 2015.

Ervens, B. and Amato, P.: The global impact of bacterial processes on carbon mass, Atmos. Chem. Phys., 20, 1777-1794, https://doi.org/10.5194/acp-20-1777-2020, 2020.

Ervens, B., George, C., Williams, J. E., Buxton, G. V., Salmon, G. A., Bydder, M., Wilkinson, F., Dentener, F., Mirabel, P., Wolke, R., and Herrmann, H.: CAPRAM 2.4 (MODAC mechanism): An extended and condensed tropospheric aqueous phase mechanism and its application, J. Geophys. Res.-Atmos., 108, 4426, https://doi.org/10.1029/2002jd002202, 2003a.

Ervens, B., Herckes, P., Feingold, G., Lee, T., Collett, J. L., and Kreidenweis, S. M.: On the drop-size dependence of organic acid 
and formaldehyde concentrations in fog, J. Atmos. Chem., 46, 239-269, https://doi.org/10.1023/A:1026393805907, 2003b.

Ervens, B., Gligorovski, S. and Herrmann, H.: Temperaturedependent rate constants for hydroxyl radical reactions with organic compounds in aqueous solutions, Phys. Chem. Chem. Phys., 5, 1811-1824, https://doi.org/10.1039/b300072a, 2003c.

Ervens, B., Feingold, G., Frost, G. J., and Kreidenweis, S. M.: A modeling of study of aqueous production of dicarboxylic acids: 1. Chemical pathways and speciated organic mass production, J. Geophys. Res., 109, D15205, https://doi.org/10.1029/2003JD004387, 2004.

Ervens, B., Carlton, A. G., Turpin, B. J., Altieri, K. E., Kreidenweis, S. M., and Feingold, G.: Secondary organic aerosol yields from cloud-processing of isoprene oxidation products, Geophys. Res. Lett., 35, L02816, https://doi.org/10.1029/2007GL031828, 2008.

Exner, M., Herrmann, H., and Zellner, R.: Rate constants for the reactions of the $\mathrm{NO}_{3}$ radical with $\mathrm{HCOOH} / \mathrm{HCOO}^{-}$ and $\mathrm{CH}_{3} \mathrm{COOH} / \mathrm{CH}_{3} \mathrm{COO}^{-}$in aqueous solution between 278 and $328 \mathrm{~K}$, J. Atmos. Chem., 18, 359-378, https://doi.org/10.1007/BF00712451, 1994.

Fankhauser, A. M., Antonio, D. D., Krell, A., Alston, S. J., Banta, S., and McNeill, V. F.: Constraining the Impact of Bacteria on the Aqueous Atmospheric Chemistry of Small Organic Compounds, ACS Earth Sp. Chem., 3, 1485-1491, https://doi.org/10.1021/acsearthspacechem.9b00054, 2019.

Fu, P., Kawamura, K., Usukura, K., and Miura, K.: Dicarboxylic acids, ketocarboxylic acids and glyoxal in the marine aerosols collected during a round-the-world cruise, Mar. Chem., 148, 2232, https://doi.org/10.1016/j.marchem.2012.11.002, 2013.

Gaillard De Sémainville, P., Hoffmann, D., George, C. and Herrmann, H.: Study of nitrate radical (NO3) reactions with carbonyls and acids in aqueous solution as a function of temperature, Phys. Chem. Chem. Phys., 9, 958-968, https://doi.org/10.1039/b613956f, 2007.

Gao, Y., Lee, S. C., Huang, Y., Chow, J. C., and Watson, J. G.: Chemical characterization and source apportionment of sizeresolved particles in Hong Kong sub-urban area, Atmos. Res., 170, 112-122, https://doi.org/10.1016/j.atmosres.2015.11.015, 2016.

Guan, N. and Liu, L.: Microbial response to acid stress: mechanisms and applications, Appl. Microbiol. Biotechnol., 51-65, https://doi.org/10.1007/s00253-019-10226-1, 2020.

Haddrell, A. E. and Thomas, R. J.: Aerobiology: Experimental considerations, observations, and future tools, Appl. Environ. Microbiol., 83, e00809-17, https://doi.org/10.1128/AEM.00809-17, 2017.

Herckes, P., Valsaraj, K. T., and Collett, J. L.: A review of observations of organic matter in fogs and clouds: Origin, processing and fate, Atmos. Res., 132-133, 434-449, https://doi.org/10.1016/j.atmosres.2013.06.005, 2013.

Herlihy, L. J., Galloway, J. N., and Mills, A. L.: Bacterial utilization of formic and acetic acid in rainwater, Atmos. Environ., 21, 2397-2402, https://doi.org/10.1016/0004-6981(87)90374-X, 1987.

Herrmann, H.: Kinetics of Aqueous Phase Reactions Relevant for Atmospheric Chemistry, Chem. Rev., 103, 4691-4716, https://doi.org/10.1021/cr020658q, 2003.

Hoffmann, E. H., Tilgner, A., Wolke, R., Böge, O., Walter, A., and Herrmann, H.: Oxidation of substituted aromatic hydrocarbons in the tropospheric aqueous phase: Kinetic mechanism development and modelling, Phys. Chem. Chem. Phys., 20, 1096010977, https://doi.org/10.1039/c7cp08576a, 2018.

Hu, W., Niu, H., Murata, K., Wu, Z., Hu, M., Kojima, T., and Zhang, D.: Bacteria in atmospheric waters: Detection, characteristics and implications, Atmos. Environ., 179, 201-221, https://doi.org/10.1016/j.atmosenv.2018.02.026, 2018.

Husárová, S., Vaïtilingom, M., Deguillaume, L., Traikia, M., Vinatier, V., Sancelme, M., Amato, P., Matulová, M., and Delort, A. M.: Biotransformation of methanol and formaldehyde by bacteria isolated from clouds. Comparison with radical chemistry, Atmos. Environ., 45, 6093-6102, https://doi.org/10.1016/j.atmosenv.2011.06.035, 2011.

Jaber, S., Lallement, A., Sancelme, M., Leremboure, M., Mailhot, G., Ervens, B., and Delort, A.-M.: Biodegradation of phenol and catechol in cloud water: comparison to chemical oxidation in the atmospheric multiphase system, Atmos. Chem. Phys., 20, 4987 4997, https://doi.org/10.5194/acp-20-4987-2020, 2020.

Jacob, D. J.: Chemistry of $\mathrm{OH}$ in remote clouds and its role in the production of formic acid and peroxymonosulfate, J. Geophys. Res., 91, 9807-9826, https://doi.org/10.1029/jd091id09p09807, 1986.

Johnson, B. J., Betterton, E. A., and Craig, D.: Henry's Law coefficients of formic and acetic acids, J. Atmos. Chem., 24, 113-119, https://doi.org/10.1007/BF00162406, 1996.

Kaprelyants, A. S. and Kell, D. B.: Dormancy in stationary-phase cultures of Micrococcus luteus: Flow cytometric analysis of starvation and resuscitation, Appl. Environ. Microbiol., 59, 31873196, https://doi.org/10.1128/aem.59.10.3187-3196.1993, 1993.

Kawamura, K. and Ikushima, K.: Seasonal Changes in the Distribution of Dicarboxylic Acids in the Urban Atmosphere, Environ. Sci. Technol., 27, 2227-2235, https://doi.org/10.1021/es00047a033, 1993.

Khan, M. A. H., Ashfold, M. J., Nickless, G., Martin, D., Watson, L. A., Hamer, P. D., Wayne, R. P., Canosa-Mas, C. E., and Shallcross, D. E.: Night-time $\mathrm{NO}_{3}$ and $\mathrm{OH}$ radical concentrations in the United Kingdom inferred from hydrocarbon measurements, Atmos. Sci. Lett., 9, 140-146, https://doi.org/10.1002/asl.175, 2008.

Khare, P., Kumar, N., Kumari, K. M., and Srivastava, S. S.: Atmospheric formic and acetic acids: An overview, Rev. Geophys., 37, 227-248, https://doi.org/10.1029/1998RG900005, 1999.

Krumins, V., Mainelis, G., Kerkhof, L. J., and Fennell, D. E.: Substrate-Dependent rRNA Production in an Airborne Bacterium, Environ. Sci. Technol. Lett., 1, 376-381, https://doi.org/10.1021/ez500245y, 2014a.

Krumins, V., Mainelis, G., Kerkhof, L. J., and Fennell, D. E.: Substrate-Dependent rRNA Production in an Airborne Bacterium, Environ. Sci. Technol. Lett., 1, 376-381, https://doi.org/10.1021/ez500245y, 2014b.

Lelieveld, J. and Crutzen, P. J.: The role of clouds in tropospheric photochemistry, J. Atmos. Chem., 12, 229-267, https://doi.org/10.1007/BF00048075, 1991.

Löflund, M., Kasper-Giebl, A., Schuster, B., Giebl, H., Hitzenberger, R., and Puxbaum, H.: Formic, acetic, oxalic, malonic and succinic acid concentrations and their contribution to organic carbon in cloud water, Atmos. Environ., 36, 1553-1558, https://doi.org/10.1016/S1352-2310(01)00573-8, 2002. 
Lu, P., Ma, D., Chen, Y., Guo, Y., Chen, G. Q., Deng, H., and Shi, Y.: L-glutamine provides acid resistance for Escherichia coli through enzymatic release of ammonia, Cell Res., 23, 635-644, https://doi.org/10.1038/cr.2013.13, 2013.

Madronich, S. and Calvert, J. G.: The NCAR Master Mechanism of the Gas Phase Chemistry - Version 2.0, No. NCAR/TN333+STR, University Corporation for Atmospheric Research, https://doi.org/doi10.5065/D6HD7SKH, 1989.

Mezyk, S. P., Cullen, T. D., Rickman, K. A., and Mincher, B. J.: The Reactivity of the Nitrate Radical $\left(\mathrm{NO}_{3}\right)$ in Aqueous and Organic Solutions, Int. J. Chem. Kinet., 49, 635-642, https://doi.org/10.1002/kin.21103, 2017.

Mouchel-Vallon, C., Deguillaume, L., Monod, A., Perroux, H., Rose, C., Ghigo, G., Long, Y., Leriche, M., Aumont, B., Patryl, L., Armand, P., and Chaumerliac, N.: CLEPS 1.0: A new protocol for cloud aqueous phase oxidation of VOC mechanisms, Geosci. Model Dev., 10, 1339-1362, https://doi.org/10.5194/gmd-10-1339-2017, 2017.

Pillar, E. A., Camm, R. C., and Guzman, M. I.: Catechol oxidation by ozone and hydroxyl radicals at the airwater interface, Environ. Sci. Technol., 48, 14352-14360, https://doi.org/10.1021/es504094x, 2014.

Razika, B., Abbes, B., Messaoud, C., and Soufi, K.: Phenol and Benzoic Acid Degradation by Pseudomonas aeruginosa, J. Water Resour. Prot., 2, 1-4, https://doi.org/10.4236/jwarp.2010.29092, 2010.

Sander, R.: Compilation of Henry's law constants (version 4.0) for water as solvent, Atmos. Chem. Phys., 15, 4399-4981, https://doi.org/10.5194/acp-15-4399-2015, 2015.

Sattler, B., Puxbaum, H., and Psenner, R.: Bacterial growth in supercooled cloud droplets, Geophys. Res. Lett., 28, 239-242, https://doi.org/10.1029/2000GL011684, 2001.

Schwartz, S. E.: Mass-Transport Considerations Pertinent to Aqueous Phase Reactions of Gases in Liquid-Water Clouds, in: Chemistry of Multiphase Atmospheric Systems, edited by: Jaeschke, W., Springer, Berlin, Heidelberg, NATO ASI Series, Series G: Ecological Sciences, vol 6., https://doi.org/10.1007/978-3-64270627-1_16, 1986.
Seinfeld, J. H. and Pandis, S. N.: Atmospheric Chemistry and Physics, John Wiley \& Sons, New York, 1998.

Sun, X., Wang, Y., Li, H., Yang, X., Sun, L., Wang, X., Wang, T., and Wang, W.: Organic acids in cloud water and rainwater at a mountain site in acid rain areas of South China, Environ. Sci. Pollut. Res., 23, 9529-9539, https://doi.org/10.1007/s11356-0166038-1, 2016.

Tilgner, A., Bräuer, P., Wolke, R., and Herrmann, H.: Modelling multiphase chemistry in deliquescent aerosols and clouds using CAPRAM3.0i, J. Atmos. Chem., 70, 221-256, https://doi.org/10.1007/s10874-013-9267-4, 2013.

Vaïtilingom, M., Amato, P., Sancelme, M., Laj, P., Leriche, M., and Delort, A. M.: Contribution of microbial activity to carbon chemistry in clouds, Appl. Environ. Microbiol., 76, 23-29, https://doi.org/10.1128/AEM.01127-09, 2010.

Vaïtilingom, M., Charbouillot, T., Deguillaume, L., Maisonobe, R., Parazols, M., Amato, P., Sancelme, M., and Delort, A.-M.: Atmospheric chemistry of carboxylic acids: microbial implication versus photochemistry, Atmos. Chem. Phys., 11, 8721-8733, https://doi.org/10.5194/acp-11-8721-2011, 2011.

Vaîtilingom, M., Deguillaume, L., Vinatier, V., Sancelme, M., Amato, P., Chaumerliac, N., and Delort, A.-M.: Potential impact of microbial activity on the oxidant capacity and organic carbon budget in clouds, P. Natl. Acad. Sci. USA, 110, 559-564, https://doi.org/10.1073/pnas.1205743110, 2013.

Woo, J. L. and McNeill, V. F.: simpleGAMMA v1.0 - a reduced model of secondary organic aerosol formation in the aqueous aerosol phase (aaSOA), Geosci. Model Dev., 8, 1821-1829, https://doi.org/10.5194/gmd-8-1821-2015, 2015.

Zhang, M., Khaled, A., Amato, P., Delort, A.-M., and Ervens, B.: The effect of biological particles and their ageing processes on aerosol radiative properties: Model sensitivity studies, Atmos. Chem. Phys. Discuss. [preprint], https://doi.org/10.5194/acp2020-781, in review, 2020. 